\title{
Work-Life Balance, Management Practices and Productivity
}

\author{
Nick Bloom ${ }^{1}$, Tobias Kretschmer ${ }^{2}$ and John Van Reenen ${ }^{3}$ \\ April 2006 \\ ${ }^{1}$ Dept. Economics, Stanford \& Centre for Economic Performance, London School of Economics \\ ${ }^{2}$ Dept. Management \& Centre for Economic Performance, London School of Economics \\ ${ }^{3}$ Dept. Economics \& Centre for Economic Performance, London School of Economics
}

\begin{abstract}
$\underline{\text { Abstract: }}$
Many critics of free-market liberalism argue that higher product-market competition and the "Anglo-Saxon" management practices it stimulates increases productivity only at the expense of employees' work-life balance (WLB). The empirical basis of these claims is unclear. To address this issue we use an innovative survey tool to collect the first international data on management practices and work-life balance practices, surveying 732 medium sized manufacturing firms in the US, France, Germany and the UK. We find that WLB outcomes are significantly associated with better management, so that well run firms are both more productive and better for their employees. After controlling for management practices, however, we find no additional relationship between WLB and productivity. WLB practices are also not reduced by tougher competition, suggesting no deleterious effect of competition on employees' working environment. Finally, looking at multinationals we find that US subsidiaries in Europe adopt the superior management practices of their US parent firms but the local WLB practices of their European competitors.
\end{abstract}

JEL Code: O32, O33, L31

Keywords: Work-life balance, family-friendly work practices, management practices, productivity, competition.

Contact details: nbloom@stanford.edu; t.kretschmer@lse.ac.uk; j.vanreenen@lse.ac.uk

Acknowledgements: We would like to thank the Anglo-German Foundation for their generous financial support. 


\section{INTRODUCTION}

Does good management and higher productivity come at the expense of work-life balance (WLB), or is good work-life balance an important component of the management of successful firms? Some more "pessimistic" critics of globalization have argued that competition stimulates Anglo-Saxon management practices that may raise productivity but only at the expense of wellbeing at work. For example, Jacques Chirac, the French president has stressed that:

"[Europe's] model is the social market economy, [the] alliance of liberty and solidarity, with the public authority safeguarding the public interest. [...] France will therefore never let Europe become a mere free-trade area. We want a political and social Europe rooted in solidarity." 1

By contrast, a more optimistic view is often justified by citing the tangible and intangible business benefits of good WLB, sometimes espoused by the more optimistic Human Resource Management literature. For example, Tony Blair the UK Prime minister stated:

"The UK has shown it is possible to have flexible labour markets combined with [...] family friendly policies to help work/life balance [...]. The result has been higher growth, higher employment and low unemployment." ${ }^{2}$

Given the slower productivity growth of Europe relative to the US since the mid-1990s ${ }^{3}$ this question features prominently in the implementation of "catching-up strategies". If productivity and WLB are in direct conflict, employees may be asked to make sacrifices of the quality of their worklife balance. On the other hand, if favorable work-life balance is not in the way of high productivity growth or is even productivity-enhancing, the "European social model" may have a brighter future.

Recent policy debates have focused on issues surrounding or directly addressing issues of WLB. For example, the European Working Time Directive has been under intense scrutiny recently, with several governments in Continental Europe challenging workers' right to opt-out of the maximum ceiling of 48 hours a week. While at the same time, the European Services Directive designed to liberalize the movement of service workers between countries has been interpreted as intensifying foreign competition, which may exert a heavy toll on the work-life balance of workers.

On both sides of the argument, there seem to be underlying assumptions regarding the interaction between productivity and WLB. The question of WLB-enhancing practices, their implementation

\footnotetext{
1 Euractiv, "Blair, Chirac in drive to win citizens' support”, 27/10/2005 (http://www.euractiv.com/Article?tcmuri=tcm:29-146484-16\&type=News).

2 Toby Helm and David Rennie, "Blair attack on “out-of-date” Chirac”, Daily Telegraph, 25/03/2005 (http://www.telegraph.co.uk/news/main.jhtml?xml=/news/2005/03/25/weu25.xml\&sSheet=/news/2005/03/25/ixnewstop. html).

${ }^{3}$ See, for example, O’Mahony and Van Ark, 2003
} 
and effectiveness has recently been taken up in the management literature, which generally finds that:

i) WLB measures have a positive effect on firm or workplace performance ${ }^{4}$

ii) WLB measures are more effective in situations demanding high employee flexibility and responsiveness ${ }^{5}$

iii) Firms with a more skilled workforce are more likely to implement WLB-enhancing practices $^{6}$

This leaves us with a dilemma: policymakers are concerned that firms are failing to introduce sufficient measures to ensure a sensible work-life balance for their employees because the costs of doing this are too high in competitive global markets. On the other hand, the academic literature seems to believe all firms should be adopting better WLB schemes given their apparently positive impact on firm performance, particularly in more competitive markets.

Our study sheds light on these contrasting views using a new large dataset on over 700 firms in the Europe and the US, that contains rich firm performance, management and WLB variables. We are able to show that many of the prior results in the literature disappear when controls for management practice are included. We have already found in other previous work (Bloom and Van Reenen, 2006) that well managed firms tend to be more productive; in this paper we show that better managed firms also have better WLB practices. This can be seen in Figure 1 where we simply plot our WLB outcome measure against an overall index of firm management quality (we explain the exact definitions in more detail below). Consequently, the association between firm productivity and WLB practices found elsewhere in the literature may simply be due to omitted variable bias these regressions do not control for management quality. We show in this paper that once we condition on management practices in the production function there is no independent role for WLB on productivity. Failure to control for the omitted variable of management leads to the spurious associations of better WLB with productivity.

\footnotetext{
${ }^{4}$ Delaney and Huselid, 1996; Huselid, Jackson and Schuler, 1997; Konrad and Mangel, 2000; Perry-Smith and Blum, 2000; Guthrie, 2001; Budd and Mumford, forthcoming; Gray, 2002.

5 For example, in high-technology industries (Arthur, 2003) or in highly differentiated firms (Lee and Miller, 1999; Guthrie et al., 2002; Youndt et al. 1996).

${ }^{6}$ Gray and Tudball (2003); Osterman (1995). The percentage of female employees has a weakly positive effect on the implementation of WLB practices - see Harel et al., 2003; Gray and Tudball, 2003; Miliken et al., 1998; Martins et al.,, 2002; Perry-Smith and Blum, 2000; Guthrie and Roth, 1999.
} 
The structure of the paper is as follows: in section II, we discuss our general models of management practices and firm performance. In section III, we provide a detailed discussion of our datasets and the procedures used to collect this. In section IV, we discuss our results and in section $\mathrm{V}$, we provide some concluding comments. A detailed set of empirical appendices then follows.

\section{Figure 1: The Correlation Between Work-Life Balance Outcomes and Management Practices}

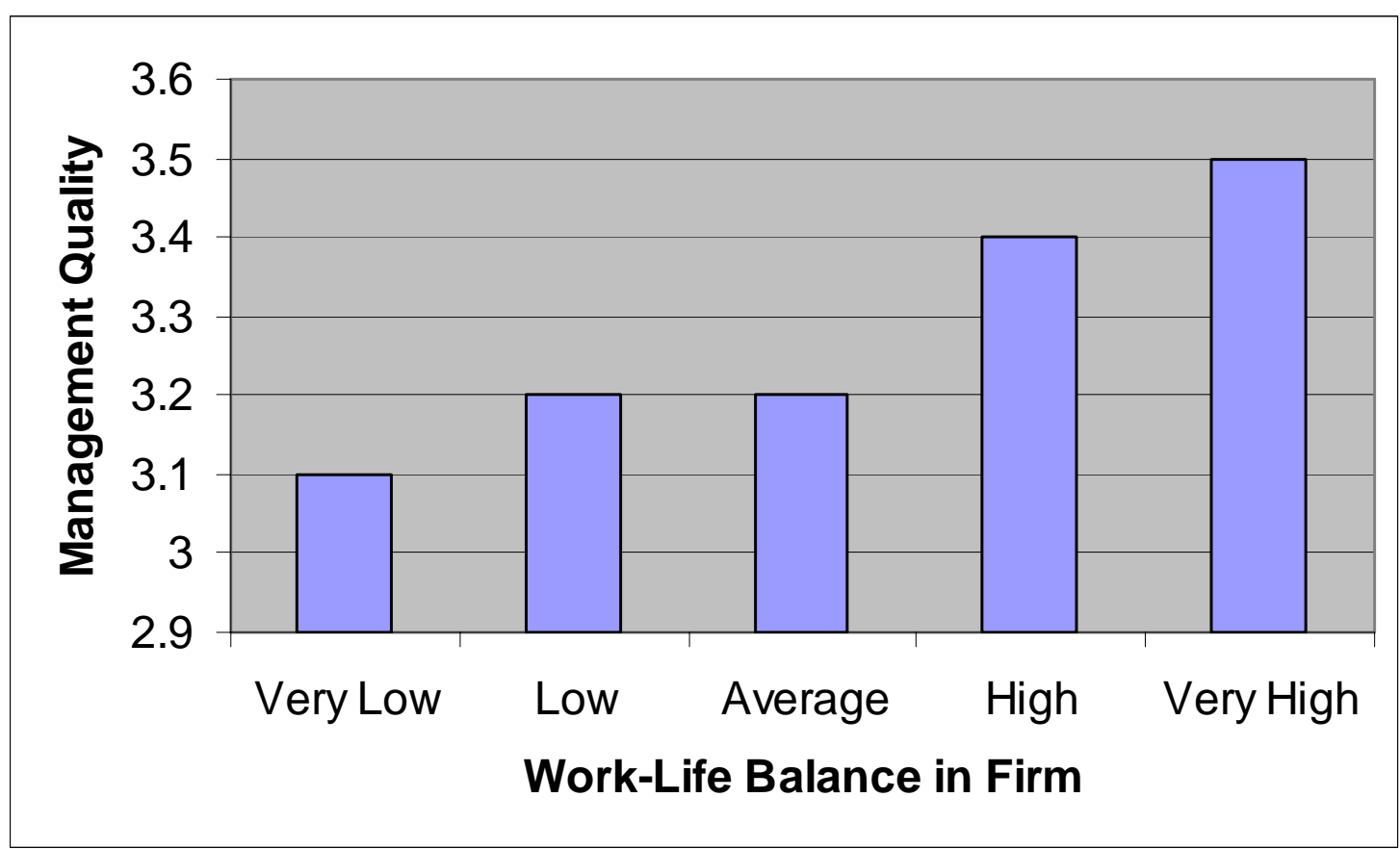

Notes: "Work-Life Balance in Firm" is the response to the question: "Relative to other companies in your industry how much does your company emphasize work-life balance?", where scores are as follows: "Much less" (1); "Slightly less" (2); "The same" (3); "Slightly more" (4); and "Much more" (5). "Management quality" is the average score for the 18 individual management practice questions with scores ranging from 1 (worst-practice) to 5 (best practice). Results from 530 firm observations. 


\section{MODELLING APPROACH}

Consider a simple approach of characterizing the above approaches:

$$
\begin{gathered}
w=f(X, M, D) \\
y=g(X, M, D)
\end{gathered}
$$

where $\mathrm{w}=$ Work-life Balance outcomes and $\mathrm{y}=$ (total factor) productivity outcomes. $\mathrm{X}$ is an index of "good" WLB practices (such as childcare flexibility and subsidies) and M is an index of "good" management practices (such as better shop-floor operations or stronger incentives). We will model these as being composite measures of several underlying practices so $M=m\left(M_{1}, M_{2}, M_{3}, \ldots.\right)$ and $X$ $=\mathrm{x}\left(\mathrm{X}_{1}, \mathrm{X}_{2}, \mathrm{X}_{3}, \ldots.\right)$. Finally, $D$ is other control variables such as firm size, firm age, industry effects and country dummies, etc.

We would expect that better management practices should be associated with improved productivity so $\frac{\partial y}{\partial M} \geq 0$ (see Bloom and Van Reenen, 2006, for extensive evidence). We would also expect that better WLB practices should be associated with improved reported WLB outcomes so $\frac{\partial w}{\partial X} \geq 0$ : this is the first thing that we examine empirically in the paper.

What is much less clear are the cross partials in equations (1) and (2). Pessimists argue that improved WLB is costly in terms of productivity and will therefore be heavily resisted by employers - which is one reason for tough labor regulation ${ }^{7}$. In the context of equation (1) this implies $\frac{\partial y}{\partial X} \leq 0$. Similarly, pessimists argue that "Anglo-Saxon" management practices come at the expense of WLB so $\frac{\partial w}{\partial M} \leq 0$.

By contrast, optimists from some parts of the Human Resource Management field often argue for a "win-win" view that improving WLB practices will increase productivity as it improves employee well-being - leading to improved recruitment and retention (e.g. of women) and better morale and motivation. In this case, $\frac{\partial y}{\partial X} \geq 0$. They generally also argue that better management tends to be

\footnotetext{
${ }^{7}$ Even if WLB practices improved productivity they may still be resisted by employers if the costs of implementing these policies were less than their productivity benefits.
} 
complementary with better WLB practices and, at a minimum, there is no obvious reason why they should be strong substitutes. Thus, $\frac{\partial w}{\partial M} \geq 0$

These cross partials are with respect to endogenous variables chosen by firms, so it is not obvious how to interpret these relationships. Nevertheless, the examination of the correlations with new data should be informative. More directly however, we also consider the more fundamental drivers of these practices. Consider a set of factors $\mathrm{Z}\left(=\mathrm{Z}_{1}, \mathrm{Z}_{2}, \mathrm{Z}_{3}, \ldots\right.$ ) that may exogenously affect the practices. We model management practices and WLB practices as functions of the exogenous variables as:

$$
X=h(Z, D) \text { and } M=j(Z, D)
$$

We are particularly interested in product market competition as one of the elements of Z. Under the pessimist view tougher product competition caused by globalization, liberalization and new technologies may increase productivity through improved management practices $\frac{\partial M}{\partial Z} \geq 0$, but this will be at the expense of worse WLB practices and outcomes, i.e. $\frac{\partial X}{\partial Z} \leq 0$. We examine these predictions directly in the empirical work. The optimists also view competition as a force promoting better management practices, but by contrast with the pessimists they argue that this should increase the use of good WLB practices. This is because, in their view, firms are making mistakes by not introducing better WLB practices and competition should make such profit-sacrificing strategies more costly.

To summarize, these two models provide a set of predictions laid out in Table 1 which we subsequently take to the data. Of course, there can be "hybrid" positions between these positions. In short, we find that the evidence is inconsistent with the negative view: management practices are positively associated with WLB outcomes and there is no evidence that competition reduces WLB for workers. Nevertheless, the positive view does not receive unambiguous support: although better management and better WLB do sometimes go together, the positive correlation between WLB and productivity found elsewhere in the literature is not robust. Once we control for management we find 
no association of WLB with productivity. We find the evidence supports a hybrid view between the optimistic and pessimistic extremes.

\section{DATA}

To investigate these issues we first have to construct robust measures of WLB, management practices, and competition. We discuss the collection of management and WLB data first (which was undertaken using a new firm survey tool) and then the collection of productivity and competition data which was taken from more standard firm and industry data sources.

The data is detailed in Table B1 in the Appendix. Figures 2 and 3 plot some of the key cross-country averages. Looking at Figure 2 there is a surprisingly large cross-country variation in hours worked, with French managers working about $68 \%$ of the annual hours worked by US managers due to a combination of fewer hours per week, longer holidays and more sick leave. UK and German managers work about $82 \%$ and $84 \%$ of the US managers' hours ${ }^{8}$; about equidistant between France and the US.

In Figure 3 we plot the share of women in the workforce at the managerial and non-managerial level. Looking first at non-managerial female involvement, we see this is higher in the US with around one third of non-managerial workers female in the US compared to about one quarter in Europe. While this difference is large, the gap at the managerial level is even greater. Only $12 \%$ of French managers are female compared to $31 \%$ in the US. Hence, not only do US firms have more female employees absolutely but they also appear to have relatively more female managers. Thus, at a first glance the French policy of regulating working hours does not seem to have been effective at ensuring female participation in the workforce, and particularly in the managerial workforce, which is often seen as an indirect indicator of work-life balance.

\footnotetext{
${ }^{8}$ The surprisingly high hours is for German managers rather than workers - who work less than their UK counterparts.
} 
Figure 2: Managerial hours vary widely by country

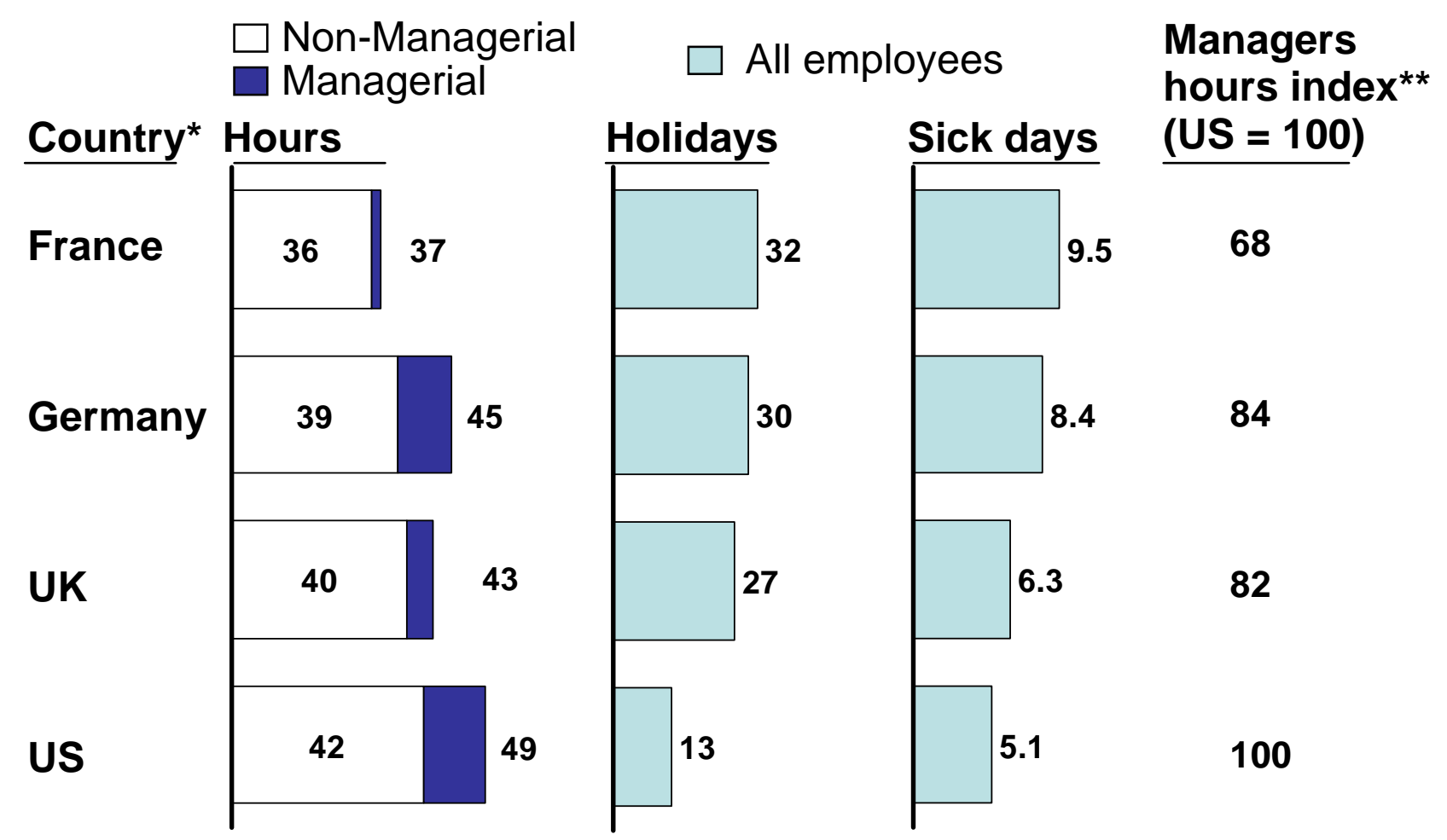

Notes: *Country averages, per year except hours which are per week.

** Average managerial hours. Assumes managers take "All employee" levels of holidays and sick leave, plus take 10 days public holidays per year.

Source: Survey of 732 manufacturing firms. 
Figure 3: Manager Gender Distribution by country

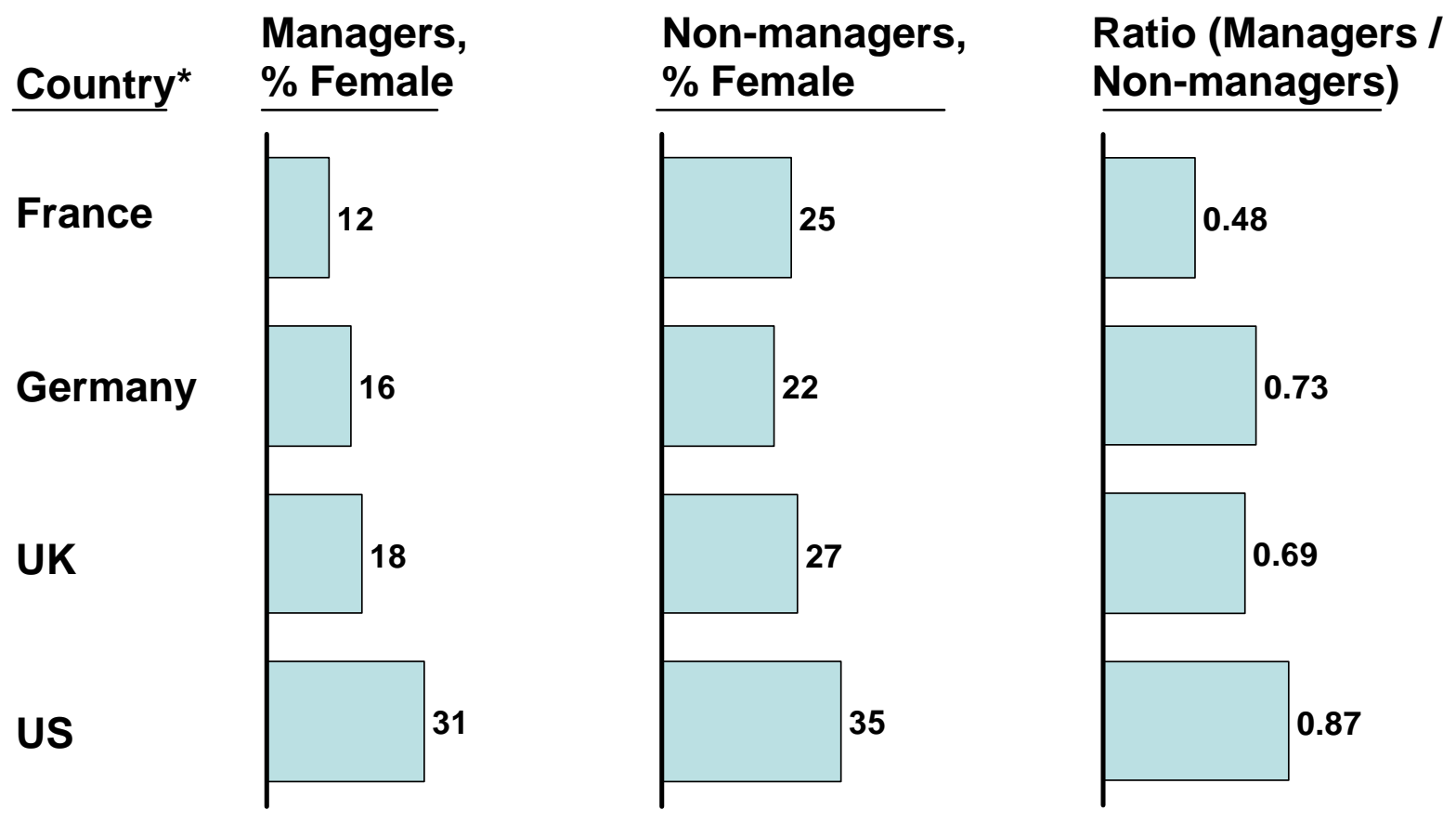

Notes: Country averages

Source: Survey of 732 manufacturing firms

\section{III.A Scoring WLB and Management Practices}

Measuring WLB and management practices requires codifying these concepts into something widely applicable across different firms. This is a hard task as WLB and good management are tough to define. To do this we combined questions that have been used previously in the: (i) Workplace Employment Survey (WERS); (ii) a management practice evaluation tool developed by a leading international management consultancy firm; and (iii) the prior economics and management academic literature.

Work-life Balance

In Appendix A2 we detail the Human Resources Interview guide which was used to collect a range of detailed WLB practices and characteristics from firms. We collected three types of key data: 
- The first was the WLB perceptions data of individuals' on their own firms WLB versus other firms in the industry. This was used as our WLB outcome measure, defined as the response to the question: "Relative to other companies in your industry how much does your company emphasize work-life balance?”, scored as: Much less (1); Slightly less (2); The same (3); Slightly more (4); Much more (5).

- The second was the WLB policies/practices data on key variables including childcare flexibility, home-working entitlements, part-time to full-time job flexibility, job-sharing schemes and childcare subsidy schemes. This was used to construct our WLB practice measure defined as the average $\mathrm{z}$-score ${ }^{9}$ from the five questions: "If an employee needed to take a day off at short notice due to child-care problems or their child was sick how do they generally do this?”; and the entitlements to "Working at home in normal working hours", "Switching from full-time to part-time work", "Job sharing schemes” and "Financial subsidy to help pay for childcare”. These are all ranked on a scale of 1 to 5 .

- The third was workforce characteristic data on key variables including average employee age, hours, holidays and proportion female, plus a full set of conditioning variables on skills (the proportion of college educated), training and unionization. We used this data as a control for heterogeneity across firms.

\section{Management Practices}

In Appendix A1 we detail the practices and the questions in the same order as they appeared in the survey, describe the scoring system and provide three anonymous responses per question. These practices can be grouped into four areas: operations (3 practices), monitoring (5 practices), targets (5 practices) and incentives (5 practices). The operations management section focuses on the introduction of lean manufacturing techniques, the documentation of processes improvements and the rationale behind introductions of improvements. The monitoring section focuses on the tracking of the performance of individuals, reviewing performance (e.g. through regular appraisals and job plans), and consequence management (e.g. making sure that plans are kept and appropriate sanctions and rewards are in place). The targets section examines the type of targets (whether goals are simply financial or operational or more holistic), the realism of the targets (stretching, unrealistic or non-

\footnotetext{
${ }^{9}$ For comparability to the management z-score this WLB z-score (and the management z-score) were both re-normalized to zero mean with standard deviation one. Hence, the coefficients on both the management and WLB practice z-scores in the tables of results both respond to one standard deviation change in both measures.
} 
binding), the transparency of targets (simple or complex) and the range and interconnection of targets (e.g. whether they are given consistently throughout the organization). Finally, incentives (or people management) include promotion criteria, pay and bonuses, and fixing or firing bad performers, where best practice is deemed to be an approach that gives strong rewards for those with both ability and effort. A subset of the practices has similarities with those used in studies on HRM practices, such as Ichniowski, Shaw and Prenushi (1997), Black and Lynch (2001) and Bartel et al. (2004).

Since the scaling may vary across practices in the econometric estimation, we convert the scores (from the 1 to 5 scale) to z-scores by normalizing by practice to mean zero and standard deviation one. In our main econometric specifications, we take the unweighted average across all z-scores as our primary measure of overall managerial practice ${ }^{10}$, but we also experiment with other weightings schemes based on factor analytic approaches.

There is legitimate scope for disagreement over whether all of these measures really constitute "good practice". Therefore, an important way to examine the externality validity of the measures is to examine whether they are correlated with data on firm performance constructed from company accounts and the stock market.

\section{III.B Collecting Accurate Responses}

With this evaluation tool we can, in principle, provide some quantification of firms' WLB and management practices. However, an important issue is the extent to which we can obtain unbiased responses to questions from firms. In particular, will respondents provide accurate responses? As is well known in the surveying literature (see, for example, Bertrand and Mullainathan, 2001) a respondent's answer to survey questions is typically biased by the scoring grid and anchored towards those answers that they expect the interviewer thinks is "correct". In addition, interviewers may themselves have preconceptions about the performance of the firms they are interviewing and bias their scores based on their ex-ante perceptions. More generally, a range of background characteristics, potentially correlated with good and bad managers, may generate some kinds of systematic bias in the survey data.

To try to address these issues we took a range of steps to obtain accurate data:

\footnotetext{
${ }^{10}$ This management z-score was then re-normalized to zero mean and standard deviation one.
} 
- First, the survey was conducted by telephone without telling the managers they were being scored. ${ }^{11}$ This enabled scoring to be based on the interviewer's evaluation of the actual firm practices, rather than the firm's aspirations, the manager's perceptions or the interviewer's impressions. ${ }^{12}$ To run this "blind” scoring we used open questions (i.e. "Can you tell me how you promote your employees.”), rather than closed questions (i.e. “Do you promote your employees on tenure [yes/no]?”). These questions target actual practices and examples, with the discussion continuing until the interviewer could make an accurate assessment of the firm's typical practices. Typically about three or four questions were needed to score each practice.

- Second, the interviewers did not know anything about the firm's financial information or performance in advance of the interview. This was achieved by selecting medium sized manufacturing firms and by providing only firm names and contact details to the interviewers (but no financial details). These smaller firms would typically not be known by name and are rarely reported in the business media. The interviewers were specially trained graduate students from top European and US business schools, with a median age of twentyeight and five years prior business experience in the manufacturing sector ${ }^{13}$. All interviews were conducted in the manager's native language.

- Third, each interviewer ran over 50 interviews on average, allowing us to remove interviewer fixed effects from all empirical specifications. This helped us to address concerns over inconsistent interpretation of categorical responses (see Manski, 2004), standardizing the scoring system.

- Fourth, the survey instrument was targeted at plant managers, who are typically senior enough to have an overview of management practices but not so senior as to be detached from day-to-day operations of the enterprise.

- Fifth, a detailed set of information was also collected on the interview process itself (number and type of prior contacts before obtaining the interviews, duration, local time-of-day, date

\footnotetext{
${ }^{11}$ This survey tool has been passed by Stanford's Human Subjects Committee. The deception involved was deemed acceptable because it is: (i) necessary to get unbiased responses; (ii) minimized to the management practice questions and is temporary (we send managers debriefing packs afterwards); and (iii) presents no risk as the data is confidential.

${ }^{12}$ If an interviewer could not score a question it was left blank, with the firm average taken over the remaining questions. The average number of un-scored questions per firm was $1.3 \%$, with no firm included in the sample if more than three questions were un-scored.

${ }^{13}$ Thanks to the interview team of Johannes Banner, Michael Bevan, Mehdi Boussebaa, Dinesh Cheryan, Alberic de Solere, Manish Mahajan, Simone Martin, Himanshu Pande, Jayesh Patel and Marcus Thielking.
} 
and day-of-the week), on the manager (gender, seniority, nationality, company and job tenure, internal and external employment experience, and location), and on the interviewer (we can include individual interviewer-fixed effects, time-of-day and a subjective reliability score assigned by the interviewer). Some of these survey controls are significantly informative about the management score (see Table C1) ${ }^{14}$, and when we use these as controls for interview noise in our econometric evaluations the coefficient on the management score typically increased (see Bloom and Van Reenen, 2006).

\section{III.C Obtaining Interviews with Managers}

The interview process took about 50 minutes on average, and was run from the London School of Economics. Overall, we obtained a high response rate of 54\%, which was achieved through four steps.

- First, the interview was introduced as “a piece of work"15 without discussion of the firm's financial position or its company accounts, making it relatively uncontroversial for managers to participate. Interviewers did not discuss financials in the interviews, both to maximize the participation of firms and to ensure our interviewers were truly "blind" on the firm's financial position.

- Second, questions were ordered to lead with the least controversial (shop-floor management) and finish with the most controversial (pay, promotions and firings). The WLB questions were placed at the end of the interview to ensure the most candor in the response to this.

- Third, interviewers' performance was monitored, as was the proportion of interviews achieved, so they were persistent in chasing firms (the median number of contacts each interviewer had per interview was 6.4). The questions are also about practices within the firm that any plant manager can respond to, so there were potentially several managers per firm who could be contacted ${ }^{16}$.

\footnotetext{
${ }^{14}$ In particular, we found the scores were significantly higher for senior managers, when interviews were conducted later in the week and/or earlier in the day. That is to say, scores were highest, on average, for senior managers on a Friday morning and lowest for junior managers on a Monday afternoon. By including information on these characteristics in our analysis, we explicitly controlled for these types of interview bias.

${ }^{15}$ Words like "survey" or "research" should be avoided as these are used by switchboards to block market research calls.

${ }^{16}$ We found no significant correlation between the number, type and time-span of contacts before an interview is conducted and the management score. This suggests while different managers may respond differently to the interview
} 
- Fourth, written endorsement of the Bundesbank (in Germany) and the Treasury (in the UK), and a scheduled presentation to the Banque de France, helped demonstrate to managers this was an important exercise with official support.

\section{III.D Sampling Frame and Additional Data}

Since our aim was to compare across countries we decided to focus on the manufacturing sector where productivity is easier to measure than in the non-manufacturing sector. We also focused on medium sized firms selecting a sample where employment ranged between 50 and 10,000 workers (with a median of 700). Very small firms have little publicly available data. Very large firms are likely to be more heterogeneous across plants, and it would be more difficult to get a picture of managerial performance in the firm as a whole from one or two plant interviews. We drew a sampling frame from each country to be representative of medium sized manufacturing firms and then randomly chose the order of which firms to contact (see Appendix B for details). We also excluded any clients of our partnering consultancy firm from our sampling frame ${ }^{17}$.

Comparing the responding firms with those in the sampling frame, we found no evidence that the responders were systematically different to the non-responders on any of the performance measures. They were also statistically similar on all the other observables in our dataset. The only exception was on size where our firms were slightly larger than average than those in the sampling frame.

\section{III.E Evaluating and Controlling for Potential Measurement Error}

To quantify possible measurement error in the WLB and management practice scores obtained using our survey tool, we performed repeat interviews on management practice data on 64 firms contacting different managers in the firm, typically at different plants, using different interviewers. To the extent that our measures are truly picking up general company-wide practices these two scores should be correlated, while to the extent that our measures are driven by noise these should be independent.

Figure 4 plots the average firm-level management scores from the first interview against the second interview, from which we can see that they are highly correlated (correlation 0.734 with p-value

proposition this does not appear to be directly correlated with their responses or the average management practices of the firm.

${ }^{17}$ This removed 33 firms out of our sampling frame of 1,353 firms. 
0.000). Furthermore, there is no obvious (or statistically significant) relationship between the degree of measurement error and the absolute score. That is to say, high and low scores appear to be as well measured as average scores, and firms that have high (or low) scores on the first interview tend to have high (or low) scores on the second interview. Thus, firms that score below two or above four on the 1-5 scale of composite management scores appear to be genuinely badly or well managed rather than extreme draws of sampling measurement error.

\section{III.F Productivity and Competition Data}

Quantitative information on firm sales, employment, capital, materials etc. came from the company accounts and proxy statements, and was used to calculate firm level productivity. The details are provided in Appendix B. To measure competition we follow Nickell (1996) and Aghion et al. (2005) in using three broad measures. The first measure is the degree of import penetration in the country by three-digit industry measured as the share of total imports over domestic production. This is constructed for the period 1995-1999 to remove any potential contemporaneous feedback. The second is the country by three-digit industry Lerner index of competition, which is (1 profits/sales), calculated as the average across the entire firm level database (excluding each firm itself) ${ }^{18}$. Again, this is constructed for the period 1995-1999 to remove any potential contemporaneous feedback. The third measure of competition is the survey question on the number of competitors a firm faces (see Appendix A2), valued zero for "no competitors”, one for "less than 5 competitors", and two for " 5 or more competitors"19.

\section{RESULTS}

The first thing we look at is whether our key measure of WLB outcomes were correlated with the practices that we might expect to improve employee WLB. If this did not turn out to be true, we would suspect that the WLB outcome measure was not really reflecting the actual events on the ground but rather some other unobservable firm-specific characteristic.

\footnotetext{
${ }^{18}$ Note that in constructing this we draw on firms in the population database, not just those in the survey.

${ }^{19}$ This question has been used by inter alia Nickell (1996) and Stewart (1990).
} 


\section{Figure 4: The Management Scoring Appears Reliable}

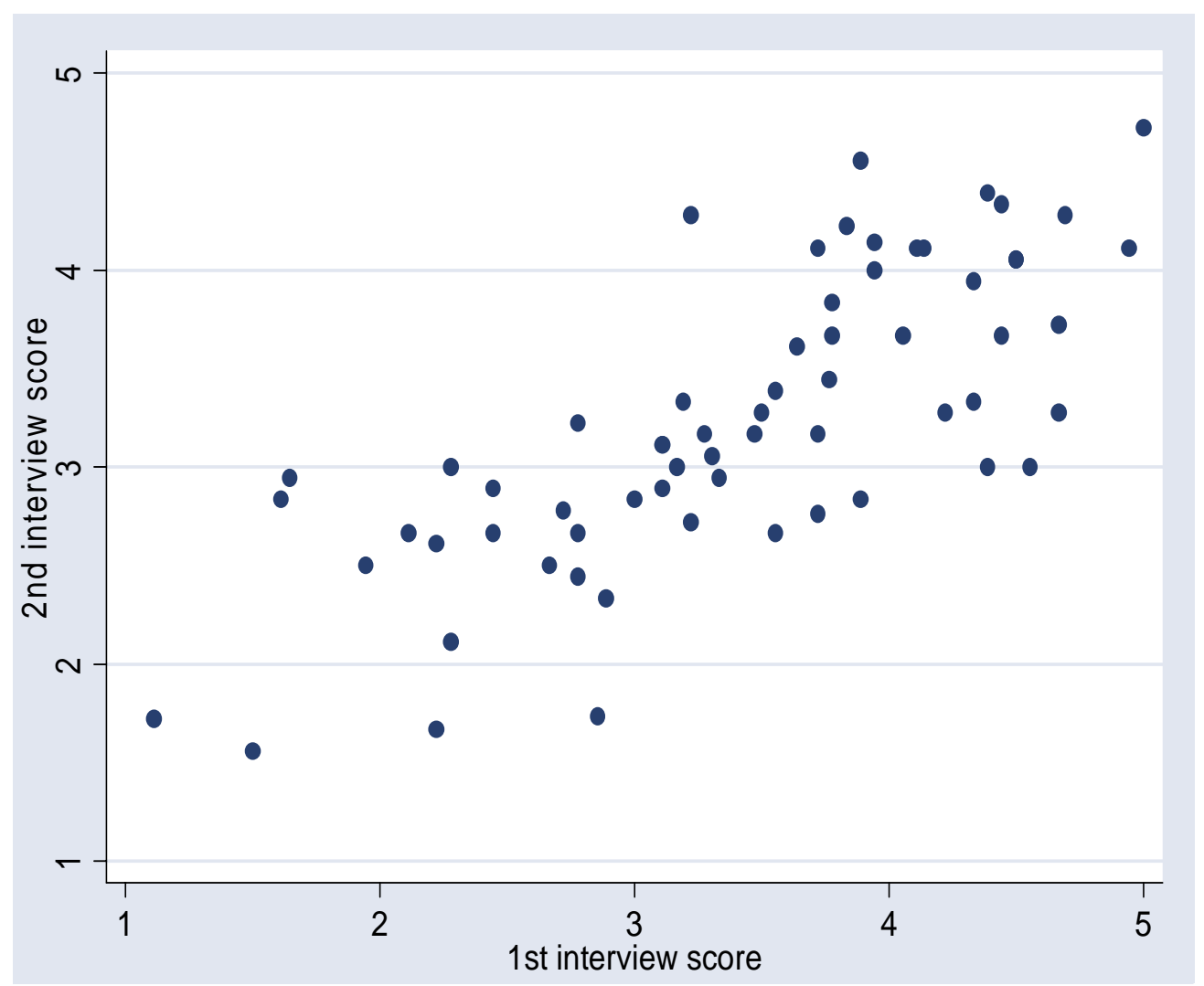

Note: Scores from 64 repeat interviews on the same firm with different managers and different interviewers.

\section{IV.A WLB Practices and WLB Outcomes}

Table 2 examines this issue by regressing the WLB outcome indicator on a number of variables that we would expect to be associated with better work-life balance. Reassuringly we find that all the associations are sensible.

Column (1) simply correlates WLB with average hours worked per week in the firm across all employees. An extra 10 hours a week worked is associated with a 0.4 points lower WLB score (about 12\% lower than the mean of 3.21). This association is significant at the $5 \%$ level. In the second column we control for four country dummies, firm size, whether the firm is publicly listed and firm age. With the exception of the country dummies ${ }^{20}$ and firm size all other variables are

\footnotetext{
${ }^{20}$ The pattern of the country dummies suggests that conditional on other factors, Germans report the worst work-life balance and Americans report the best work-life balance. It is difficult to interpret these results, however, as the WLB question is relative to the industry average so this implicitly removes the country effect if managers compare themselves
} 
insignificant. The coefficient on managerial hours stays essentially the same ${ }^{21}$. Column (3) includes the number of days’ holiday per year - more holidays are associated with a higher WLB score.

We next consider the composite WLB practices z-score (the average z-score across the five practices - working from home, job switching, job sharing, childcare flexibility and childcare subsidy). When we include this WLB practice score into the regression in column (4), the variable is positive and highly significant. The next five columns show the correlation of WLB with each of the five practices individually.

Firms that are flexible and allow some working from home (column (5)), job switching (column (6)) and job sharing (column (7)) also have higher reported WLB outcomes. The next two columns show that firms who have more family-friendly policies with regard to allowing flexibility for employees to take time off for children ${ }^{22}$ or offer childcare subsidies also score more highly on WLB. All of these correlations are significant and consistent with the notion that the WLB outcome measure reflects something real about the WLB policies in the firm.

The final column includes the proportion of female managers in the regression. Firms who have a greater proportion of female managers are also more likely to report a higher WLB outcome. This correlation is specifically related to the proportion of female managers, not females in the workplace as a whole. The share of females in non-managerial positions is not correlated with WLB. This suggests that the correlation does not simply arise from the fact that women are more or less attracted to different firms. More likely is some combination of: (i) in firms with more female managers there is greater decision-making support for improved WLB because the balance of power is more with women; and (ii) female managers are attracted to firms with better WLB.

\section{IV.B Work-life Balance and Management}

Table 3 examines the correlation between WLB and our composite measure of good management described in the previous section. In previous work, we have found this a reliable metric of the

to other firms in the same sector in the same country. The systematically lower score in Germany could reflect a "more negative" cultural bias in answering these questions.

${ }^{21}$ If we split total hours into average hours worked by managers and average hours worked by non-managers both variables are negatively related to WLB at the $10 \%$ significance level or higher, suggesting WLB is related to the hours worked by both workers and managers.

${ }^{22}$ Response to the question "If an employee needed to take a day off at short notice due child-care problems or their child was sick how do they generally do this?”, where this variable was ordered conceptually as: $1=$ Not allowed; $2=$ Allowed but unpaid; and 3 = Allowed and paid. Hence, we allocated the responses to the scores as follows: A score of 1 for "Not Allowed" or "Never been asked"; a score of 2 for "Take as leave without pay" or "Take time off but make it up later" and a score of 3 for "Take as annual leave" or "Take as sick leave". 
overall degree of managerial quality in the firm and the management score is strongly correlated with superior firm performance. Is it the case that firms who adopt these better "Anglo-Saxon" management practices do so at the expense of employees’ work-life balance?

In the first column of Table 3, we regress WLB outcome measure on the average management score and nothing else. There is a strong positive and significant correlation between the two variables. The second column then includes the composite score of the WLB practices. This is also positive and highly significant. The third column includes the "standard" vector of controls (firm size, firm age, country dummies, listing status and controls for measurement error in the survey such as interviewer fixed effects). Both variables remain positive and significant. The fourth column includes skills and multinational status as additional controls. The skills measure - the proportion of workers with degrees - is significant at the $5 \%$ level. Hence, firms with higher skilled employees also tend to have better work-life balance practices. After including these additional controls, the management coefficient falls further and is now only significant at the $10 \%$ level. Hence, while WLB practices play a strong role in influencing the WLB outcomes, management practices per se play only a weak role in influencing these, after including a full set of control variables.

We then disaggregate our management measure into four components - operations, monitoring, targets and people management (incentives). Interestingly, the WLB measure is correlated with each of these positively when entered individually into the regression (columns (5) through (8)), but only people management/incentives is significant at the $5 \%$ level. Thus, it appears that while WLB practices are linked with good management, this is much stronger for people management practices than other types of management practices.

\section{IV.C Competition, Work-life Balance and Management}

Having established the correlations of WLB with several factors, we now turn to the key hypotheses on competition and productivity. Our previous research found that tougher product market competition drives higher productivity ${ }^{23}$ and at least part of this seems to work through improving management practices (Bloom and Van Reenen, 2006). Nevertheless, does competition damage work-life balance?

Table 4 examines this question in detail. We measure competition by the degree of openness to trade (columns (1) and (2)), the degree of “excess profit” in the industry (columns (3) and (4)) or simply

\footnotetext{
${ }^{23}$ On the relationship between productivity and competition see also inter alia Nickell (1996) and Syverson (2004a,b).
} 
the number of competitors (columns (4) and (5)). In column (1) import competition is weakly and positively associated with better WLB, but this association disappears when we include the additional controls in column (2). A similar picture emerges in the other columns - competition is essentially uncorrelated with WLB outcomes. We conclude that although competition seems to improve management, it does not seem to reduce WLB.

We also estimated the relationship between competition and the WLB practices examined later in section IV.D - working from home flexibility, job switching flexibility, flexibility for childcare time off and childcare subsidies - and found no significant relationships. We could not find any relationship between average hours worked per week or days holidays per year and competition. So we confirm the earlier conclusion that although competition seems to improve management, it does not seem to be associated with worse WLB outcomes or practices. While higher competition appears to increase management practices by removing the worst managed/least productive firms from the market it does not seem to affect WLB. This is presumably because - as we show in the next section - WLB practices and productivity are essentially unrelated, so that the Darwinian selection effects of competition have no bearing on typical WLB practices.

\section{IV.D Productivity, Work-life Balance and Management}

Perhaps the most important issue is the association of WLB with productivity. We address this issue in Table 5 that shows the results from simple production functions. We must always remember the caveat that these are associations and we cannot simply infer causality. The dependent variable is the log of real sales and because we control for the factor inputs (labour, capital and materials) the coefficient on WLB practices should be interpreted as the "effect” on Total Factor (or revenue) Productivity (TFP).

Column (1) of Table 5 reports the first specification that also includes country and industry dummies and basic controls (firm age, listing status and a consolidation dummy). The association of WLB and productivity is positive and significant at the $5 \%$ level. This is the kind of regression highlighted in the Human Resource Management literature that is often used to justify policies to introduce better WLB practices.

Column (2) of Table 5 simply conditions on our management z-score, which enters the production function with a positive and highly significant coefficient. The WLB practices variable, by contrast, falls in magnitude and is no longer significant at even the $10 \%$ level. When we condition on a wider 
set of controls in the next column (skills, multinational status, listing, and firm age), the management variable remains positive and significant (see Bloom and Van Reenen, 2006) but the WLB practices variable is now negative, albeit completely insignificant.

Table 5 suggests that the significant association of WLB with productivity is spurious and arises because WLB is correlated with an important omitted variable - good management. Firms with better management practices will tend to have both higher productivity and better work-life balance. This gives rise (in column (1)) to the mistaken impression that better WLB causes higher productivity.

\section{IV.E Multinationals, Work-life Balance and Management}

Finally, in Table 6 we examine some of the cross-country differences in WLB practices and management practices. The first column simply regresses the composite WLB practice measure on the country dummies (the US is the omitted base). It is clear that the US has worse WLB practices than the European countries and France has better WLB practices than the UK or Germany. The second column includes dummy variables indicating whether for the European based firms they are a US multinational or a non-US multinational (European domestic firms are the omitted base). ${ }^{24}$ WLB does not seem worse in US multinationals located overseas as indicated by the insignificant variable on the dummy than on the local domestic firms (and indeed the non-US multinational dummy). This does not change when we condition on the more extended covariate set in column (3). Therefore, US multinationals in Europe appear to adopt local work-life balance practices.

In contrast, columns (4) to (6) show that US multinationals in Europe bring over their better US management practices. So in Column (4) we see that on management practices the UK and France have significantly worse management practices than the US and Germany. Including the multinational controls in Column (5) we see when US multinationals are located in Europe they appear to have significantly better management practices than equivalent non-US multinationals and domestic firms (column (5)). In Column (6), we see this result is robust to including additional covariates.

\footnotetext{
${ }^{24}$ Our US firms are all publicly traded so we have no multinational subsidiaries in the US. Hence, these regressions compare between different types of European firms. Restricting the estimates to only European firms thus does not change the point estimates on the US and non-US multinationals.
} 
An interpretation of Table 6 is that US firms in general have better management practices but worse WLB policies. There are many complex reasons for these patterns. For example, although competition appears to be a reason for better US management practices it cannot seem to explain its worse WLB outcomes as we showed that competition was unrelated to WLB in Table 4. What is clear is that although US firms appear to be able to transport their better management practices to Europe (column (6)) they do not transfer their worse WLB practices to Europe (column (3)). One rationale for this could be that European regulations require US multinationals based in Europe to adopt these more worker friendly practices. However, the work-life balance practices we measure working from home, job-sharing, switching from full to part-time, childcare flexibility and childcare subsidies - are typically not directly regulated in Europe. Thus, our belief is that social norms explain much of this localization by US multinationals, with this an area of ongoing research.

\section{CONCLUSIONS}

A debate is raging all over the developed world about quality of work issues. As unemployment has fallen in the US and UK, attention has focused more on the quality rather than quantity of jobs. This has sharpened as women's participation has risen and issues of work-life balance and familyfriendly policies have risen up the political agenda. This paper has tried to shed some empirical light on these debates.

We characterized two opposing views of globalization entitled the pessimistic and the optimistic view. The pessimists argue that "savage neo-liberalism” encapsulated by tougher product market competition, globalization and “Anglo-Saxon” managerial policies are undesirable. Although these forces will raise productivity, they come at the expense of misery for workers in the form of poor work-life balance (long hours, job insecurity, intense and unsatisfying work). The optimistic Human Resource Management literature, argues that better work-life balance will, in fact, improve productivity (and even profitability) and employers are mistakenly failing to treat their workers as assets and implement better work-life balance policies.

In short, we find evidence for a hybrid view between these two extremes. Using originally collected data, we show that we have a useful firm specific measure of WLB. The pessimists' argument that “Anglo-Saxon” management practices are negatively associated with worse WLB is rejected - there is a positive association as suggested by the optimists. Similarly, the pessimists' theory that 
competition is inevitably bad for workers' WLB is also rejected: there is no significantly negative relationship. Larger firms - which are typically more globalized - also have better WLB practices on average. However, the view that WLB will improve productivity is also rejected: there is no relationship between productivity and WLB once we control for good management. Neither is there support for the pessimists’ prediction that WLB is negatively associated with productivity.

Finally, looking at US multinationals based in Europe we find an intriguing result that these firms appear to bring over their superior US management practices with them to Europe but then adopt more worker-friendly European work-life balance practices. Why US firms internationalize their management practices but localize their work-life balance practices appears to be due to a combination of regulations and social norms, an area of ongoing research. 
TABLE 1: EMPIRICAL PREDICTIONS OF DIFFERENT MODELS

\begin{tabular}{lllllll}
\hline \hline & $(1)$ & $(2)$ & $(3)$ & $(4)$ & $(5)$ & (6) \\
& $\frac{\partial w}{\partial X}$ & $\frac{\partial w}{\partial M}$ & $\frac{\partial y}{\partial X}$ & $\frac{\partial y}{\partial M}$ & $\frac{\partial X}{\partial Z}$ & $\frac{\partial M}{\partial Z}$ \\
& WLB & WLB & Productivity & Productivity & WLB & Management \\
& Outcomes & Outcomes & & & practices & Practices \\
& Derivative & Derivative & Derivative & Derivative & Derivative & Derivative \\
& w.r.t to & w.r.t to & w.r.t to & w.r.t to & w.r.t to & w.r.t to \\
& WLB & Management & WLB & Management & competition & Competition \\
& practices & Practices & practices & Practices & & \\
& & & & & & POSITIVE \\
Pessimist & POSITIVE & NEGATIVE & NEGATIVE & POSITIVE & NEGATIVE & POSITIVE \\
& & & & & & \\
\hline \hline
\end{tabular}


TABLE 2: WORK LIFE BALANCE OUTCOMES AND WLB PRACTICES

\begin{tabular}{|c|c|c|c|c|c|c|c|c|c|c|}
\hline & (1) & (2) & (3) & (4) & (5) & (6) & (7) & (8) & (9) & (10) \\
\hline $\begin{array}{l}\text { Dependent } \\
\text { variable }\end{array}$ & $\begin{array}{l}\text { WLB } \\
\text { outcome } \\
\text { score }\end{array}$ & $\begin{array}{c}\text { WLB } \\
\text { outcome } \\
\text { score }\end{array}$ & $\begin{array}{c}\text { WLB } \\
\text { outcome } \\
\text { score }\end{array}$ & $\begin{array}{l}\text { WLB } \\
\text { outcome } \\
\text { score }\end{array}$ & $\begin{array}{c}\text { WLB } \\
\text { outcome } \\
\text { score }\end{array}$ & $\begin{array}{c}\text { WLB } \\
\text { outcome } \\
\text { score }\end{array}$ & $\begin{array}{l}\text { WLB } \\
\text { outcome } \\
\text { score }\end{array}$ & $\begin{array}{l}\text { WLB } \\
\text { outcome } \\
\text { score }\end{array}$ & $\begin{array}{c}\text { WLB } \\
\text { outcome } \\
\text { score }\end{array}$ & $\begin{array}{c}\text { WLB } \\
\text { outcome } \\
\text { score }\end{array}$ \\
\hline $\begin{array}{l}\text { Hours (all } \\
\text { Employees) }\end{array}$ & $\begin{array}{c}-0.038 * * \\
(0.012)\end{array}$ & $\begin{array}{c}-0.037 * * \\
(0.012)\end{array}$ & & & & & & & & \\
\hline $\begin{array}{l}\text { Days p.a. } \\
\text { holiday }\end{array}$ & & & $\begin{array}{c}0.026 * * \\
(0.007)\end{array}$ & & & & & & & \\
\hline $\begin{array}{l}\text { WLB practices } \\
\text { z-score }\end{array}$ & & & & $\begin{array}{c}0.230 * * * \\
(0.041)\end{array}$ & & & & & & \\
\hline $\begin{array}{l}\text { Working from } \\
\text { Home allowed }\end{array}$ & & & & & $\begin{array}{c}0.286 * * \\
(0.098)\end{array}$ & & & & & \\
\hline $\begin{array}{l}\text { Full-time/part- } \\
\text { time job } \\
\text { Switching } \\
\text { allowed }\end{array}$ & & & & & & $\begin{array}{l}0.185^{*} \\
(0.094)\end{array}$ & & & & \\
\hline $\begin{array}{l}\text { Job Sharing } \\
\text { allowed }\end{array}$ & & & & & & & $\begin{array}{c}0.369 * * \\
(0.151)\end{array}$ & & & \\
\hline $\begin{array}{l}\text { Childcare } \\
\text { flexibility }\end{array}$ & & & & & & & & $\begin{array}{c}0.321^{* *} \\
(0.094)\end{array}$ & & \\
\hline $\begin{array}{l}\text { Childcare } \\
\text { subsidy }\end{array}$ & & & & & & & & & $\begin{array}{l}0.265^{* *} \\
(0.106)\end{array}$ & \\
\hline $\begin{array}{l}\text { Proportion of } \\
\text { Female } \\
\text { managers }\end{array}$ & & & & & & & & & & $\begin{array}{c}0.005^{* *} \\
(0.002)\end{array}$ \\
\hline $\begin{array}{l}\text { Firm size,ln } \\
\text { (employees) }\end{array}$ & & $\begin{array}{c}0.104^{* * *} \\
(0.036)\end{array}$ & $\begin{array}{c}0.113^{* * *} \\
(0.038)\end{array}$ & $\begin{array}{l}0.063 * \\
(0.038)\end{array}$ & $\begin{array}{c}0.097 * * * \\
(0.038)\end{array}$ & $\begin{array}{c}0.079 * * * \\
(0.037)\end{array}$ & $\begin{array}{c}0.087 * * * \\
(0.038)\end{array}$ & $\begin{array}{c}0.109 * * * \\
(0.036)\end{array}$ & $\begin{array}{c}0.084^{* * *} \\
(0.038)\end{array}$ & $\begin{array}{c}0.111^{* * *} \\
(0.037)\end{array}$ \\
\hline Controls & No & Yes & Yes & Yes & Yes & Yes & Yes & Yes & Yes & Yes \\
\hline Firms & 525 & 525 & 523 & 477 & 489 & 489 & 484 & 513 & 486 & 521 \\
\hline
\end{tabular}

NOTES: In all columns, standard errors are in parentheses under coefficient estimates and allow for arbitrary heteroskedasticity $* * *=$ significant at the $1 \%$ level, $* *=$ significant at the $5 \%$ level, *=significant at the $10 \%$ level. "WLB outcome score" is the response to the question: "Relative to other companies in your industry how much does your company emphasize work-life balance?", where scores are as follows: "Much less" (1); "Slightly less" (2); “The same” (3); "Slightly more” (4); and "Much more” (5). "WLB practices z-score” is the average z-score for the five practice "working from home allowed”, "job switching allowed”, "job sharing allowed", "childcare flexibility" and "childcare subsidy", normalized so this measure has a mean of 0 and standard deviation of 1.

"Controls" include country dummies, a dummy for public listing and the ln(age) of the firm. 
TABLE 3: WORK LIFE BALANCE (WLB) OUTCOME SCORES, WLB PRACTICES AND MANAGEMENT BEST PRACTICES

\begin{tabular}{|c|c|c|c|c|c|c|c|c|}
\hline & (1) & (2) & (3) & (4) & (5) & (6) & (7) & (8) \\
\hline $\begin{array}{l}\text { Dependent } \\
\text { variable }\end{array}$ & $\begin{array}{l}\text { WLB } \\
\text { outcome } \\
\text { score }\end{array}$ & $\begin{array}{l}\text { WLB } \\
\text { outcome } \\
\text { score }\end{array}$ & $\begin{array}{l}\text { WLB } \\
\text { outcome } \\
\text { score }\end{array}$ & $\begin{array}{l}\text { WLB } \\
\text { outcome } \\
\text { score }\end{array}$ & $\begin{array}{c}\text { WLB } \\
\text { outcome } \\
\text { score }\end{array}$ & $\begin{array}{c}\text { WLB } \\
\text { outcome } \\
\text { score }\end{array}$ & $\begin{array}{l}\text { WLB } \\
\text { outcome } \\
\text { score }\end{array}$ & $\begin{array}{l}\text { WLB } \\
\text { outcome } \\
\text { score }\end{array}$ \\
\hline $\begin{array}{l}\text { Management } \\
\text { practices z-score }\end{array}$ & $\begin{array}{c}0.139 * * * \\
(0.039)\end{array}$ & $\begin{array}{c}0.106^{* * *} \\
(0.039)\end{array}$ & $\begin{array}{l}0.097 * * \\
(0.043)\end{array}$ & $\begin{array}{l}0.079 * \\
(0.044)\end{array}$ & & & & \\
\hline $\begin{array}{l}\text { WLB practices z- } \\
\text { score }\end{array}$ & & $\begin{array}{c}0.219 * * * \\
(0.037)\end{array}$ & $\begin{array}{c}0.206^{* * *} \\
(0.045)\end{array}$ & $\begin{array}{c}0.187 * * * \\
(0.046)\end{array}$ & $\begin{array}{c}0.196 * * * \\
(0.046)\end{array}$ & $\begin{array}{c}0.191^{* * *} \\
(0.046)\end{array}$ & $\begin{array}{c}0.191^{* * *} \\
(0.046)\end{array}$ & $\begin{array}{c}0.176^{* * *} \\
(0.046)\end{array}$ \\
\hline \multicolumn{9}{|l|}{$\begin{array}{l}\text { Type of } \\
\text { management: }\end{array}$} \\
\hline Operations & & & & & $\begin{array}{c}0.023 \\
(0.035)\end{array}$ & & & \\
\hline Monitoring & & & & & & $\begin{array}{c}0.035 \\
(0.037)\end{array}$ & & \\
\hline Targets & & & & & & & $\begin{array}{c}0.042 \\
(0.037)\end{array}$ & \\
\hline People & & & & & & & & $\begin{array}{c}0.113^{* *} \\
(0.045)\end{array}$ \\
\hline $\begin{array}{l}\text { Standard } \\
\text { Controls }\end{array}$ & No & No & Yes & Yes & Yes & Yes & Yes & Yes \\
\hline Full Controls & No & No & No & Yes & Yes & Yes & Yes & Yes \\
\hline Firms & 477 & 477 & 477 & 477 & 475 & 475 & 475 & 475 \\
\hline
\end{tabular}

NOTES: In all columns, standard errors are in parentheses under coefficient estimates and allow for arbitrary heteroskedasticity $* * *=$ significant at the $1 \%$ level, **=significant at the $5 \%$ level, *=significant at the $10 \%$ level. "WLB outcome score" is the response to the question: "Relative to other companies in your industry how much does your company emphasize work-life balance?”, where scores are as follows: "Much less" (1); "Slightly less" (2); "The same" (3); "Slightly more" (4); and "Much more” (5). "Management practices z-score" is the average z-score for the 18 individual management practice scores, normalized so this measure has a mean of 0 and standard deviation of 1 . "WLB practices z-score" is the average z-score for the five practice "working from home allowed", "full-time/part-time job switching allowed”, "job sharing allowed”, "childcare flexibility” and "childcare subsidy”, normalized so this measure has a mean of 0 and standard deviation of 1 . "Standard Controls" include country dummies, a dummy for public listing, the ln(age) of the firm plus the management measure noise controls. "Full Controls" includes controls for percentage employees with degrees, percentage of employees with MBAs and a US multinational and a non-US multinational dummy. 
TABLE 4: WORK LIFE BALANCE OUTCOMES

AND PRODUCT MARKET COMPETITION

(1)

(2)

(3)

(4)

(5)

(6)

\begin{tabular}{|c|c|c|c|c|c|c|}
\hline Estimation Method & OLS & OLS & OLS & OLS & OLS & OLS \\
\hline Dependent variable & $\begin{array}{l}\text { WLB } \\
\text { outcome } \\
\text { score }\end{array}$ & $\begin{array}{l}\text { WLB } \\
\text { outcome } \\
\text { score }\end{array}$ & $\begin{array}{l}\text { WLB } \\
\text { outcome } \\
\text { score }\end{array}$ & $\begin{array}{l}\text { WLB } \\
\text { outcome } \\
\text { score }\end{array}$ & $\begin{array}{l}\text { WLB } \\
\text { outcome } \\
\text { score }\end{array}$ & $\begin{array}{l}\text { WLB } \\
\text { outcome } \\
\text { score }\end{array}$ \\
\hline $\begin{array}{l}\text { Import penetration (5-year } \\
\text { lagged) }\end{array}$ & $\begin{array}{l}0.147^{*} \\
(0.079)\end{array}$ & $\begin{array}{c}0.073 \\
(0.145)\end{array}$ & & & & \\
\hline $\begin{array}{l}\text { Lerner index of competition } \\
\text { (5-year lagged) }\end{array}$ & & & $\begin{array}{c}0.463 \\
(0.858)\end{array}$ & $\begin{array}{c}0.306 \\
(1.118)\end{array}$ & & \\
\hline Number of competitors & & & & & $\begin{array}{c}0.009 \\
(0.081)\end{array}$ & $\begin{array}{l}-0.000 \\
(0.084)\end{array}$ \\
\hline Firms & 492 & 492 & 486 & 486 & 524 & 530 \\
\hline Country controls & Yes & Yes & Yes & Yes & Yes & Yes \\
\hline Full controls & No & Yes & No & Yes & No & Yes \\
\hline
\end{tabular}

NOTES: Coefficients from OLS regressions with standard errors in parentheses (robust to arbitrary heteroskedasticity and clustered by country * industry pair); single cross-section. ${ }^{* * *}=$ significant at the $1 \%$ level, ${ }^{* *}=$ significant at the $5 \%$ level, *=significant at the $10 \%$ level. "Country controls" includes four country dummies. "Full controls" includes $\ln ($ firm size), ln(firm age), a dummy for being listed, the share of workforce with degrees, the share of workforce with MBAs, a dummy for being consolidated and the survey noise controls. "Import Penetration" = $\ln ($ Import/Production) in every country industry pair. Average over 1995-1999 used. "Lerner index of competition" constructed, as in Aghion et al. (2005), as the mean of (1 - profit/sales) in the entire database (excluding the firm itself) for every country industry pair. "Number of competitors" constructed from the response to the survey question on number of competitors, and is coded as 0 for "none" ( $1 \%$ of responses), 1 for "less than 5" (51\% of responses), and 2 for " 5 or more" ( $48 \%$ of responses). Columns (4) through (6) include, the "noise controls" of column (2) in Table A2 (17 interviewer dummies, the seniority, gender, tenure and number of countries worked in of the manager who responded, the day of the week the interview was conducted, the time of the day the interview was conducted, the duration of the interviews and an indicator of the reliability of the information as coded by the interviewer). 
TABLE 5: WORK-LIFE BALANCE PRACTICES

ARE UNRELATED TO PRODUCTIVITY

\begin{tabular}{|c|c|c|c|}
\hline & (1) & (2) & (3) \\
\hline Countries & All & All & All \\
\hline Estimation & OLS & OLS & OLS \\
\hline Dependent variable & $\underset{\text { sales }}{\operatorname{Ln}(\mathbf{Y})_{\text {it }}}$ & $\underset{\text { sales }}{\operatorname{Ln}(\mathbf{Y})_{\text {it }}}$ & $\underset{\text { sales }}{\operatorname{Ln}(Y)_{i t}}$ \\
\hline WLB practices z-score & $\begin{array}{c}0.048 * * \\
(0.023)\end{array}$ & $\begin{array}{c}0.034 \\
(0.023)\end{array}$ & $\begin{array}{l}-0.005 \\
(0.018)\end{array}$ \\
\hline Management z-score & & $\begin{array}{c}0.064^{* * *} \\
(0.023)\end{array}$ & $\begin{array}{c}0.038 * * * \\
(0.015)\end{array}$ \\
\hline $\ln (L)_{\text {it }}$ & $0.983 * * *$ & $0.978 * * *$ & $0.500 * * *$ \\
\hline labor & $(0.018)$ & $(0.018)$ & $(0.032)$ \\
\hline $\operatorname{Ln}(K)_{\text {it }}$ & & & $0.122 * * *$ \\
\hline capital & & & $(0.027)$ \\
\hline $\begin{array}{l}\text { In (Materials) it, } \\
\text { materials }\end{array}$ & & & $\begin{array}{c}0.370 * * * \\
(0.032)\end{array}$ \\
\hline Basic Controls & Yes & Yes & Yes \\
\hline Full controls & No & No & Yes \\
\hline Firms & 481 & 481 & 481 \\
\hline
\end{tabular}

NOTES: In all columns, standard errors are in parentheses under coefficient estimates and allow for arbitrary heteroskedasticity. $* * *=$ significant at the $1 \%$ level, $* *=$ significant at the $5 \%$ level, $*=$ significant at the $10 \%$ level. Basic controls include country and industry dummies, $\log ($ firm age), public listing and consolidated dummy. Full control s include industry dummies, $\log ($ firm age), public listing, \% of workforce with degrees, \% of employees with MBAs, US multinational dummy and non-US multinational dummy. "Management practices z-score" is the average z-score for the 18 individual management practice scores, normalized so this measure has a mean of 0 and standard deviation of 1. "WLB practices z-score" is the average z-score for the five practice "working from home allowed”, "full-time/part-time job switching allowed”, "job sharing allowed”, "childcare flexibility” and "childcare subsidy”, normalized so this measure has a mean of 0 and standard deviation of 1. 
TABLE 6: WORK-LIFE BALANCE AND MANAGEMENT PRACTICES IN DOMESTIC AND MULTINATIONAL FIRMS

\begin{tabular}{|c|c|c|c|c|c|c|}
\hline & (1) & (2) & (3) & (4) & (5) & (6) \\
\hline Countries & All & All & All & All & All & All \\
\hline Estimation & OLS & OLS & OLS & OLS & OLS & OLS \\
\hline Dependent variable & $\begin{array}{c}\text { WLB } \\
\text { practices } \\
\text { z-score }\end{array}$ & $\begin{array}{c}\text { WLB } \\
\text { practices } \\
\text { z-score }\end{array}$ & $\begin{array}{c}\text { WLB } \\
\text { practices } \\
\text { z-score }\end{array}$ & $\begin{array}{c}\text { Management } \\
\text { practices } \\
\text { z-score }\end{array}$ & $\begin{array}{l}\text { Management } \\
\text { practices } \\
\text { z-score }\end{array}$ & $\begin{array}{l}\text { Management } \\
\text { practices } \\
\text { z-score }\end{array}$ \\
\hline \multicolumn{7}{|l|}{ Baseline is US } \\
\hline Country is France & $\begin{array}{l}1.066^{* * *} \\
(0.0115)\end{array}$ & $\begin{array}{c}1.052 * * * \\
(0.117)\end{array}$ & $\begin{array}{c}1.284 * * * \\
(0.179)\end{array}$ & $\begin{array}{c}-0.270^{* * * *} \\
(0.103)\end{array}$ & $\begin{array}{c}-0.302^{* * *} \\
(0.104)\end{array}$ & $\begin{array}{l}-0.091 \\
(0.156)\end{array}$ \\
\hline Country is Germany & $\begin{array}{c}0.306^{* * *} \\
(0.109)\end{array}$ & $\begin{array}{c}0.288 * * * \\
(0.111)\end{array}$ & $\begin{array}{l}0.368^{* *} \\
(0.155)\end{array}$ & $\begin{array}{l}-0.093 \\
(0.098)\end{array}$ & $\begin{array}{l}-.0142 \\
(0.099)\end{array}$ & $\begin{array}{l}-0.067 \\
(0.156)\end{array}$ \\
\hline Country is UK & $\begin{array}{c}0.336^{* * *} \\
(0.120)\end{array}$ & $\begin{array}{c}0.320 * * * \\
(0.121)\end{array}$ & $\begin{array}{c}0.439 * * * \\
(0.166)\end{array}$ & $\begin{array}{c}-0.359 * * * \\
(0.099)\end{array}$ & $\begin{array}{c}-0.396 * * * \\
(0.100)\end{array}$ & $\begin{array}{c}-0.290 * * \\
(0.138)\end{array}$ \\
\hline $\begin{array}{l}\text { US Multinational in } \\
\text { (Europe) }\end{array}$ & & $\begin{array}{c}0.229 \\
(0.255)\end{array}$ & $\begin{array}{l}-0.059 \\
(0.215)\end{array}$ & & $\begin{array}{c}0.828 * * * \\
(0.220)\end{array}$ & $\begin{array}{c}0.679 * * * \\
(0.242)\end{array}$ \\
\hline $\begin{array}{l}\text { Non-US Multinational } \\
\text { (in Europe) }\end{array}$ & & $\begin{array}{c}0.149 \\
(0.286)\end{array}$ & $\begin{array}{c}0.059 \\
(0.291)\end{array}$ & & $\begin{array}{c}0.077 \\
(0.251)\end{array}$ & $\begin{array}{l}-0.223 \\
(0.316)\end{array}$ \\
\hline Basic Controls & No & No & Yes & No & No & Yes \\
\hline Firms & 492 & 492 & 492 & 732 & 732 & 732 \\
\hline
\end{tabular}

NOTES: In all columns, standard errors are in parentheses under coefficient estimates and allow for arbitrary heteroskedasticity. $* * *=$ significant at the $1 \%$ level, $* *=$ significant at the $5 \%$ level, *=significant at the $10 \%$ level. Basic controls include country and industry dummies, $\log ($ firm age), public listing, \% of workforce with degrees and \% of employees with MBAs. "Management practices z-score" is the average z-score for the 18 individual management practice scores, normalized so this measure has a mean of 0 and standard deviation of 1. "WLB practices z-score" is the average z-score for the five practice "working from home allowed", "full-time/part-time job switching allowed”, "job sharing allowed”, "childcare flexibility” and "childcare subsidy”, normalized so this measure has a mean of 0 and standard deviation of 1 . 


\section{BIBLIOGRAPHY}

Aghion, P., Bloom, N., Blundell, R., Griffith, R., and Howitt, P. (2005). “Competition and Innovation: An inverted U relationship.” Quarterly Journal of Economics, 120, pp. 701-728.

Arthur, M. (2003). “Share Price Reactions to Work-Family Initiatives: An Institutional Perspective.” Academy of Management Journal, 46, pp. 497-505.

Bartel, A., Ichniowski, C., and Shaw, K. (2004). “Using 'Insider Econometrics' to Study Productivity.” American Economic Review, 94, pp. 217-23.

Bartelsman, E., Becker, R. and Gray, W. (2000). “The NBER Manufacturing Productivity Database.” NBER, Cambridge, MA.

Bertrand, M. and Mullainathan, S. (2001). "Do People Mean What they Say? Implications for Subjective Survey Data.” American Economic Review Papers and Proceedings, 91, pp. 67-72.

Black, S. and Lynch, L. (2001). "How to Compete: The Impact of Workplace Practices and Information Technology on Productivity.” Review of Economics and Statistics, 83, pp. 434445.

Bloom, N. and Van Reenen, J. (2006). “Measuring and Explaining Management Practices across firms and nations” Centre for Economic Performance Discussion Paper No. 716.

Bresnahan, T., Brynjolfsson, E. and Hitt, L. (2002), “Information Technology, Workplace Organization and the Demand for Skilled Labor: Firm-level Evidence”, Quarterly Journal of Economics, 339-376.

Budd, J. and Mumford, K. (forthcoming). "Family-Friendly Work Practices in Britain: Availability and Effective Coverage”. Human Resource Management, forthcoming.

Delaney, J. and Huselid, M. (1996). “The Impact of Human Resource Management Practices on Perceptions of Organizational Performance”. Academy of Management Journal, 39, pp. 949969.

Gray, H. (2002). “Family-Friendly Working: What a Performance! An Analysis of the Relationship between the Availability of Family Friendly Policies and Establishment Performance”. CEP Discussion Paper No. 529.

Gray, M., and Tudball, J. (2003). “Family-Friendly Work Practices: Differences within and between Workplaces”. Journal of Industrial Relations, 45, pp. 269-291. 
Guthrie, J. (2001). “High-Involvement Work Practices, Turnover, and Productivity: Evidence from New Zealand”. Academy of Management Journal, 44, pp. 180-190.

Guthrie, J. and Roth, L. (1999). “The State, Courts and Maternity Policies in US Organizations: Specifying Institutional Arrangements”. American Sociological Review, 64, pp. 41-63.

Guthrie, J., Spell, C., and Nyamori, R. (2002). “Correlates and Consequences of High Involvement Work Practices: The Role of Competitive Strategy”. International Journal of Human Resource Management, 13, pp. 183-197.

Harel, G., Tzafrir, S., and Baruch, Y. (2003). “Achieving Organizational Effectiveness through Promotion of Women into Managerial Positions: HRM Practice Focus”. International Journal of Human Resource Management, 14, pp. 247-263.

Huselid, M., Jackson, S. and Schuler, R. (1997). “Technical and Strategic Human Resource Management Effectiveness as Determinants of Firm Performance”. Academy of Management Journal, 40, pp. 171-188.

Ichniowski, C., Shaw, K. and Prenushi, G. (1997). "The Effects of Human Resource Management: A Study of Steel Finishing Lines”. American Economic Review, 87, pp. 291-313

Konrad, A. and Mangel, R. (2000). "The Impact of Work-Life Programs on Firm Productivity”. Strategic Management Journal, 21, pp. 1225-1237.

Lee, J. and Miller, D. (1999). “People Matter: Commitment to Employees, Strategy and Performance in Korean Firms”. Strategic Management Journal, 20, pp. 579-593.

Manski, C. (2004). “Measuring expectations”. Econometrica, 72, pp. 1329-1376.

Martins, L., Eddleston, K., and Veiga, J. (2002). "Moderators of the Relationship between WorkFamily Conflict and Career Satisfaction”. Academy of Management Journal, 45, pp. 399-409.

Miliken, F., Martins, L., and Morgan, H. (1998). “Explaining Organizational Responsiveness to Work-Family Issues: The Role of Human Resource Executives as Issue Interpreters”. Academy of Management Journal, 41, pp. 580-592.

Nickell, S. (1996). “Competition and Corporate Performance”. Journal of Political Economy, 104, pp. 724-746. 
O'Mahony, M. and van Ark, B. (eds.) (2003). "EU Productivity and Competitiveness: An Industry Perspective. Can Europe Resume the Catching-up Process?” Office for Official Publications of the European Communities, Luxembourg.

Osterman, P. (1995). “Work/Family Programs and the Employment Relationship”. Administrative Science Quarterly, 40, pp. 681-700.

Perry-Smith, J. and Blum, T. (2000). "Work-Family Human Resource Bundles and Perceived Organizational Performance”. Academy of Management Journal, 43, pp. 1107-1117.

Pfeffer, J. (1983). Competitive Advantage through People. Harvard University Press, Cambridge, MA.

Schuler, R. and MacMillan, I. (1984). "Gaining Competitive Advantage through Human Resource Practices”. Human Resource Management, 23, pp. 241-255.

Stewart, M (1990). “Union Wage Differentials, Product Market Influences and the Division Of Rents”. Economic Journal, 100, pp. 1122-1137.

Syverson, C. (2004a). “Market Structure and Productivity: A Concrete Example”. Journal of Political Economy, 112, pp. 1181-1222

Syverson, C. (2004b). “Product substitutability and Productivity Dispersion”. Review of Economics and Statistics, 86, pp. 534-50.

Youndt, M., Snell, S., Dean, J., and Lepak, D. (1996). “Human Resource Management, Manufacturing Strategy, and Firm Performance”. Academy of Management Journal, 39, pp. 836-866. 


\section{APPENDIX A1: MANAGEMENT PRACTICE INTERVIEW GUIDE AND EXAMPLE RESPONSES}

Any score from 1 to 5 can be given, but the scoring guide and examples are only provided for scores of 1, 3 and 5 . Multiple questions are used for each dimension to improve scoring accuracy.

(1) Modern manufacturing, introduction

a) Can you describe the production process for me?

b) What kinds of lean (modern) manufacturing processes have you introduced? Can you give me specific examples?

c) How do you manage inventory levels? What is done to balance the line? What is the Takt time of your manufacturing processes?

\section{Score 1}

Scoring grid: Other than JIT delivery from suppliers few modern manufacturing techniques have been introduced, (or have been introduced in an ad-hoc manner)

Examples: $\quad$ A UK firm orders in bulk and stores the material on average 6 months before use. The business focuses on quality and not reduction of lead-time or costs. Absolutely no modern manufacturing techniques had been introduced.

\section{Score 3}

Some aspects of modern manufacturing techniques have been introduced, through informal/isolated change programs

A supplier to the army is undergoing a full lean transformation. For 20 years, the company was a specialty supplier to the army, but now they have had to identify other competencies forcing them to compete with lean manufacturers. They have begun adopting specific lean techniques and plan to use full lean by the end of next year.
Score 5

All major aspects of modern manufacturing have been introduced (Just-in-time, autonomation, flexible manpower, support systems, attitudes and behaviour) in a formal way

A US firm has formally introduced all major elements of modern production. It reconfigured the factory floor based on value stream mapping and 5-S principles, broke production into cells, eliminated stockrooms,

implemented Kanban, and adopted Takt time analyses to organize workflow.

(2) Modern manufacturing, rationale

a) Can you take through the rationale to introduce these processes?

b) What factors led to the adoption of these lean (modern) management practices?

Score 1

Scoring grid:

Examples:
Score 3

Modern manufacturing techniques were introduced because others were using them.

A German firm introduced modern techniques because all its competitors were using these techniques. The business decision had been taken to imitate the competition.

\section{Score 5}

Modern manufacturing techniques were introduced to reduce costs

A French firm introduced modern manufacturing methods primarily to reduce costs.
Modern manufacturing techniques were introduced to enable us to meet our business objectives (including costs)

A US firm implemented lean techniques because the COO had worked with them before and knew that they would enable the business to reduce costs, competing with cheaper imports through improved quality, flexible production, greater innovation and JIT delivery. 
(3) Process problem documentation

a) How would you go about improving the manufacturing process itself?

b) How do problems typically get exposed and fixed?

c) Talk me through the process for a recent problem.

d) Do the staff ever suggest process improvements?

\section{Score 1}

Scoring grid: $\quad$ No, process improvements are made when problems occur.

Examples:

A US firm has no formal or informal mechanism in place for either process documentation or improvement. The manager admitted that production takes

place in an environment where nothing has been done to encourage or support process

\section{Score 3}

mprovements are made in one week workshops involving all staff, to improve performance in their area of the plant

A US firm takes suggestions via an anonymous box, they then review these each week in their section meeting and decide any that they would like to proceed with.
Score 5

Exposing problems in a structured way is integral to individuals' responsibilities and resolution occurs as a part of normal business processes rather than by extraordinary effort/teams

The employees of a German firm constantly analyse the production process as part of their normal duty. They film critical production steps to analyse areas more thoroughly. Every problem is registered in a special database that monitors critical processes and each issue must be reviewed and signed off by a manager.

(4) Performance tracking innovation.

a) Tell me how you track production performance?

b) What kind of KPI's would you use for performance tracking? How frequently are these measured? Who gets to see this KPI data?

c) If I were to walk through your factory could I tell how you were doing against your KPI's?

\section{Score 1}

Scoring grid:

Measures tracked do not indicate directly if overall business objectives are being met. Tracking is an ad-hoc process (certain processes aren’t tracked at all)

Examples:
A manager of a US firm tracks a range of measures when he does not think that output is sufficient. He last requested these reports about 8 months ago and had them printed for a week until output increased again.

\section{Score 3}

Most key performance indicators are tracked formally. Tracking is overseen by senior management.

At a US firm every product is bar-coded and performance indicators are tracked throughout the production process; however, this information is not communicated to workers
Score 5

Performance is continuously tracked and communicated, both formally and informally, to all staff using a range of visual management tools.

A US firm has screens in view of every line. These screens are used to display progress to daily target and other performance indicators. The manager meets with the shop floor every morning to discuss the day past and the one ahead and uses monthly company meetings to present a larger view of the goals to date and strategic direction of the business to employees. He even stamps napkins with key performance achievements to ensure everyone is aware of a target that has been hit. 
a) How do you review your KPI's?

b) Tell me about a recent meeting

c) Who is involved in these meetings? Who gets to see the results of this review?

d) What are the typical next steps after a meeting?

\section{Score 1}

Scoring grid:

Performance is reviewed infrequently or in an un-meaningful way e.g. only success or failure is noted.

Examples:

A manager of a US firm relies heavily on his gut feel of the business. He will review costs when he thinks there is too much or too little in the stores. He admits he is busy so reviews are infrequent. He also mentioned staffs feel like he is going on a hunt to find a problem, so he has now made a point of highlighting anything good.

\section{Score 3}

Performance is reviewed periodically with successes and failures identified. Results are communicated to senior management. No clear follow-up plan is adopted.

A UK firm uses daily production meetings to compare performance to plan. However, clear action plans are infrequently developed based on these production results.
Score 5

Performance is continually reviewed, based on indicators tracked. All aspects are followed up ensure continuous improvement. Results are communicated to all staff

A French firm tracks all performance numbers real time (amount, quality etc). These numbers are continuously matched to the plan on a shift-by-shift basis. Every employee can access these figures on workstations on the shop floor. If scheduled numbers are not met, action for improvement is taken immediately.

(6) Performance dialogue

a) How are these meetings structured? Tell me about your most recent meeting

b) During these meeting do you find that you generally have enough data?

c) How useful do you find problem solving meetings?

d) What type of feedback occurs in these meetings?

\section{Score 1}

The right data or information for a constructive discussion is often not present or conversations overly focus on data that is not meaningful. Clear agenda is not known and purpose is not stated explicitly

Examples:
A US firm does not conduct staff reviews. It was just "not the philosophy of the company" to do that. The company was very successful during the last decade and therefore did not feel the need to review their performance.

\section{Score 3}

Review conversations are held with the appropriate data and information present. Objectives of meetings are clear to all participating and a clear agenda is present. Conversations do not, as a matter of course, drive to the root causes of the problems.

A UK firm focuses on key areas to discuss each week. This ensures they receive consistent management attention and everyone comes prepared. However, meetings are more of an opportunity for everyone to stay abreast of current issues rather than problem solve.

\section{Score 5}

Regular review/performance conversations focus on problem solving and addressing root causes. Purpose, agenda and follow-up steps are clear to all. Meetings are an opportunity for constructive feedback and coaching.

A German firm meets weekly to discuss performance with workers and management. Participants come from all departments (shop floor, sales, R\&D, procurement etc.) to discuss the previous week performance and to identify areas to improve. They focus on the cause of problems and agree topics to be followed up the next week, allocating all tasks to individual participants. 
a) What happens if there is a part of the business (or a manager) who isn't achieving agreed upon results? Can you give me a recent example?

b) What kind of consequences would follow such an action?

c) Are there are any parts of the business (or managers) that seem to repeatedly fail to carry out agreed actions?

Scoring grid:

Score 1

Failure to achieve agreed objectives does not carry any consequences

Examples:

Examples:
At a French firm no action is taken when objectives aren't achieved. The President personally intervenes to warn employees but no stricter action is taken. Cutting payroll or making people redundant

because of a lack of performance is very rarely done.
Score 3

Failure to achieve agreed results is tolerated for a period before action is taken.

Management of a US firm reviews performance quarterly. That is the earliest

they can react to any underperformance.

They increase pressure on the employees if targets are not met.

(8) Target balance

a) What types of targets are set for the company? What are the goals for your plant?

b) Tell me about the financial and non-financial goals?

c) What do CHQ (or their appropriate manager) emphasize to you?

\section{Score 1}

Goals are exclusively financial or operational

At a UK firm performance targets are exclusively operational. Specifically volume is the only meaningful objective for managers, with no targeting of quality, flexibility or waste.

\section{Score 3}

Goals include non-financial targets, which form part of the performance appraisal of top management only (they are not reinforced throughout the rest of organization)

For French firm strategic goals are very important. They focus on market share and try to hold their position in technology leadership. However, workers on the shop floor are not aware of those targets.

\section{Score 5}

A failure to achieve agreed targets drives retraining in identified areas of weakness or moving individuals to where their skills are appropriate

A German firm takes action as soon as a weakness is identified. They have even employed a psychologist to improve behavior within a difficult group. People receive ongoing training to improve performance. If this doesn't help they move them in other departments or even fire individuals if they repeatedly fail to meet agreed targets

\section{Score 5}

Goals are a balance of financial and non-financia targets. Senior managers believe the non-financial targets are often more inspiring and challenging than financials alone.

A US firm gives everyone a mix of operational and financial targets. They communicate financial targets to the shop floor in a way they found effective - for example telling workers they pack boxes to pay the overheads until lunchtime and after lunch it is all profit for the business. If they are having a good day the boards immediately adjust and play the "profit jingle" to let the shop floor know that they are now working for profit. Everyone cheers when the jingle is played. 
(9) Target interconnection

a) What is the motivation behind your goals?

b) How are these goals cascaded down to the individual workers?

c) What are the goals of the top management team (do they even know what they are!)?

d) How are your targets linked to company performance and their goals?

\section{Score 1}

Scoring grid: $\quad$ Goals are based purely on accounting figures (with no clear connection to shareholder value)

Examples:

A family owned firm in France is only concerned about the net income for the year. They try to maximize income every year without focusing on any long term consequences.

\section{Score 3}

Corporate goals are based on shareholder value but are not clearly communicated down to individuals

A US firm bases its strategic corporate goals on enhancing shareholder value, but does not clearly communicate this to workers. Departments and individuals have little understanding of their connection to profitability or value with many areas labeled as "cost-centers" with an objective to cost-cut despite potentially

disproportionately large negative impact on the other departments they serve.

\section{Score 5}

Corporate goals focus on shareholder value. They increase in specificity as they cascade through business units ultimately defining individual performance expectations.

For a US firm strategic planning begins with a bottom up approach that is then compared with the top down aims. Multifunctional teams meet every 6 months to track and plan deliverables for each area. This is then presented to the area head that then agrees or refines it and then communicates it down to his lowest level. Everyone has to know exactly how they contribute to the overall goals or else they won't understand how important the 10 hours they spend at work every day is to the business.

(10) Target time horizon

a) What kind of time scale are you looking at with your targets?

b) Which goals receive the most emphasis?

c) How are long term goals linked to short term goals?

d) Could you meet all your short-run goals but miss your long-run goals?

Scoring grid:

Score 1

Top management's main focus is on short term targets

A UK firm has had several years of ongoing senior management changes therefore senior managers are only focusing on how the company is doing this month versus the next, believing that long-term targets will take care of themselves.

\section{Score 3}

There are short and long-term goals for all levels of the organization. As they are set independently, they are not necessarily linked to each other

A US firm has both long and short-term goals. The long-term goals are known by the senior managers and the short-term goals are the remit of the operational managers. Operations managers only occasionally see the longer-term goals so are often unsure how they link with the short term goals.

\section{Score 5}

Long term goals are translated into specific short term targets so that short term targets become a "staircase" to reach long term goals

A UK firm translates all their goals - even their 5-year strategic goals - into short-term goals so they can track their performance to them. They believe that it is only when you make someone accountable for delivery within a sensible timeframe that a long-term objective will be met. They think it is more interesting for employees to have a mix of immediate and longer-term goals. 
a) How tough are your targets? Do you feel pushed by them?

b) On average, how often would you say that you meet your targets?

c) Are there any targets which are obviously too easy (will always be met) or too hard (will never be met)?

d) Do you feel that on targets that all groups receive the same degree of difficulty? Do some groups get easy targets?

\section{Score 1}

Scoring grid:

Goals are either too easy or impossible to achieve; managers provide low estimates to ensure easy goals

Examples:

A French firm uses easy targets to improve staff morale and encourage people. They find it difficult to set harder goals because people just give up and managers refuse to work people harder.

\section{Score 3}

In most areas, top management pushes for aggressive goals based on solid economic rationale. There are a few "sacred cows" that are not held to the same rigorous standard

A chemicals firm has 2 divisions, producing special chemicals for very different markets (military, civil). Easier levels of targets are requested from the founding and more prestigious military division.
Score 5

Goals are genuinely demanding for all divisions. They are grounded in solid, solid economic rationale

A manager of a UK firm insisted that he has to se aggressive and demanding goals for everyone - even security. If they hit all their targets he worries he has not stretched them enough. Each KPI is linked to the overall business plan.

(12) Performance clarity

a) What are your targets (i.e. do they know them exactly)? Tell me about them in full.

b) Does everyone know their targets? Does anyone complain that the targets are too complex?

c) How do people know about their own performance compared to other people's performance?

\section{Score 1 \\ Score 3}

Performance measures are complex and not clearly understood. Individual performance is not made public

Examples:
A German firm measures performance per employee based on differential weighting across 12 factors, each with its own measurement formulas (e.g. Individual versus average of the team, increase on prior performance, thresholds etc.).

Employees complain the formula is too complex to understand, and even the plant manager could not remember all the details.
Performance measures are well defined and communicated; performance is public in all levels but comparisons are discouraged

A French firm does not encourage simple individual performance measures as unions pressure them to avoid this. However, charts display the actual overall production process against the plan for teams on regular basis.

\section{Score 5}

Performance measures are well defined, strongly communicated and reinforced at all reviews; performance and rankings are made public to induce competition

At a US firm self-directed teams set and monitor their own goals. These goals and their subsequent outcomes are posted throughout the company, encouraging competition in both target setting and achievement. Individual members know where they are ranked which is communicated personally to them bi-annually.

Quarterly company meetings seek to review performance and align targets. 
(13) Managing human capital

a) Do senior managers discuss attracting and developing talented people?

b) Do senior managers get any rewards for bringing in and keeping talented people in the company?

c) Can you tell me about the talented people you have developed within your team? Did you get any rewards for this?

Scoring grid:

\section{Score 1}

Senior management do not communicate that attracting, retaining and developing talent throughout the organization is a top priority

Examples:

A US firm does not actively train or develop its employees, and does not conduct performance appraisals or employee reviews. People are seen as a secondary input to the production.

\section{Score 3}

Senior management believe and communicate that having top talent throughout the organization is a key way to win

A US firm strives to attract and retain talent throughout the organization, but does not hold managers individually accountable for the talent pool they build. The company actively cross-trains employees for development and challenges them through exposure to a variety of technologies.

(14) Rewarding high-performance

a) How does you appraisal system work? Tell me about the most recent round?

b) How does the bonus system work?

c) Are there any non-financial rewards for top-performers?

d) How does your reward system compare to your competitors?

Scoring grid:

Examples:

\section{Score 1}

People within our firm are rewarded equally irrespective of performance level

An East Germany firm pays its people equally and regardless of performance. The management said to us "there are no incentives to perform well in our company”. Even the management is paid an hourly wage, with no bonus pay.

\section{Score 3}

Our company has an evaluation system for the awarding of performance related rewards

A German firm has an awards system based on three components: the individual's performance, shift performance, and overall company performance.
Score 5

Senior managers are evaluated and held accountable on the strength of the talent pool they actively build

A UK firm benchmarks human resources practices at leading firms. A cross-functional HR excellence committee develops policies and strategies to achieve company goals. Bi-monthly directors' meetings seek to identify training and development opportunities for talented performers.
Score 5

We strive to outperform the competitors by providing ambitious stretch targets with clear performance related accountability and rewards

A US firm sets ambitious targets, rewarded through a combination of bonuses linked to performance, team lunches cooked by management, family picnics, movie passes and dinner vouchers at nice local restaurants. They also motivate staff to try by giving awards for perfect attendance, best suggestion etc. 
(15) Removing poor performers

a) If you had a worker who could not do his job what would you do? Could you give me a recent example?

b) How long would underperformance be tolerated?

c) Do you find any workers who lead a sort of charmed life? Do some individuals always just manage to avoid being fixed/fired?

\section{Score 1}

Scoring grid:

Examples:

Scoring grid:

Examples:
Poor performers are rarely removed from their positions

A French firm had a supervisor who was regularly drinking alcohol at work but no action was taken to help him or move him. In fact no employee had ever been laid off in the factory. According to the plant manager HR "kicked up a real fuss" whenever management wanted to get rid of employees, and told managers their job was production not personnel.

(16) Promoting high performers

a) Can you rise up the company rapidly if you are really good? Are there any examples you can think of?

\section{Score 3}

Suspected poor performers stay in a position for a few years before action is taken

For a German firm it is very hard to remove poor performers. The management has to prove at least three times that an individual underperformed before they can take serious action.

\section{Score 5}

We move poor performers out of the company or to less critical roles as soon as a weakness is identified

At a US firm, the manager fired four people during last couple of months due to underperformance. They continually investigate why and who are underperforming.

b) What about poor performers - do they get promoted more slowly? Are there any example you can think of?

c) How would you identify and develop (i.e. train) your star performers?

d) If two people both joined the company 5 years ago and one was much better than the other would he/she be promoted faster?

\section{Score 1}

People are promoted primarily upon the basis of tenure

A UK firm promotes based on an individual's commitment to the company measured by experience. Hence, almost all employees move up the firm in lock step. Management was afraid to change this process because it would create bad feeling among the older employees who were among the older empl
resistant to change.

\section{Score 3}

People are promoted upon the basis of performance

A US firm has no formal training program. People learn on the job and are promoted based on their performance on the job.
We actively identify, develop and promote our top performers

At a UK firm each employee is given a red light (not performing), amber light (doing well and meeting targets) a green light (consistently meeting targets very high performer) and a blue light (high performer capable of promotion of up to two levels). Each manager is assessed every quarter based on his succession plans and development plans for individuals. 
(17) Attracting human capital

a) What makes it distinctive to work at your company as opposed to your competitors?

b) If you were trying to sell your firm to me how would you do this (get them to try to do this)?

c) What don't people like about working in your firm?

\section{Score 1}

Scoring grid:

Our competitors offer stronger reasons for talented people to join their companies

Examples:

A manager of a firm in Germany could not give an example of a distinctive employee proposition and (when pushed) thinks the offer is worse than most of its competitors. He thought that people working at the firm "have drawn the short straw".

\section{Score 3}

Our value proposition to those joining our company is comparable to those offered by others in the sector

A US firm seeks to create a value proposition comparable to its competitors and other local companies by offering competitive pay, a family atmosphere, and a positive presence in the community.
Score 5

We provide a unique value proposition to encourage talented people join our company above our competitors

A German firm offers a unique value proposition through development and training programs, family culture in the company and very flexible working hours. It also strives to reduce bureaucracy and seeks to push decision making down to the lowest levels possible to make workers feel empowered and valued.

(18) Retaining human capital

a) If you had a star performer who wanted to leave what would the company do?

b) Could you give me an example of a star performers being persuaded to stay after wanting to leave?

c) Could you give me an example of a star performer who left the company without anyone trying to keep them?

Score 1

Scoring grid: $\quad$ We do little to try and keep our top talent.

Examples:
Score 3

We usually work hard to keep our top talent.

If management of a French firm feels that people want to leave the company, they talk to them about the reasons and what the company could change to keep them. This could be more responsibilities or a better outlook for the future. Managers are supposed to "take-the-pulse" of employees to check satisfaction levels.
Score 5

We do whatever it takes to retain our top talent.

A US firm knows who its top performers are and if any of them signal an interest to leave it pulls in senior managers and even corporate HQ to talk to them and try and persuade them to stay. Occasionally they will increase salary rates if necessary and if they feel the individual is being underpaid relative to the market. Managers have a responsibility to try to keep al desirable staff. 
TABLE A1: QUESTION LEVEL AVERAGES BY COUNTRY

\begin{tabular}{|c|c|c|c|c|c|c|}
\hline \multirow[b]{3}{*}{ Countries } & \multirow[t]{3}{*}{$\begin{array}{l}\text { Question } \\
\text { number }\end{array}$} & \multirow[t]{3}{*}{$\begin{array}{l}\text { Question } \\
\text { type }\end{array}$} & \multicolumn{3}{|c|}{$\begin{array}{c}\text { Average Value by Country } \\
\text { (US = 100) }\end{array}$} & \multirow{3}{*}{$\begin{array}{c}\text { Regression } \\
\text { Coefficients } \\
\text { (4) } \\
\text { All } \\
\end{array}$} \\
\hline & & & (1) & (2) & (3) & \\
\hline & & & & & & \\
\hline $\begin{array}{l}\text { Modern manufacturing, } \\
\text { introduction }\end{array}$ & 1 & Operations & $\begin{array}{c}90.0 \\
(3.50)\end{array}$ & $\begin{array}{c}86.4 \\
(3.47)\end{array}$ & $\begin{array}{l}101.3 \\
(3.63)\end{array}$ & $\begin{array}{l}0.017^{* *} \\
(0.008)\end{array}$ \\
\hline $\begin{array}{l}\text { Modern manufacturing, } \\
\text { rationale }\end{array}$ & 2 & Operations & $\begin{array}{c}92.9 \\
(3.35)\end{array}$ & $\begin{array}{l}101.5 \\
(3.32)\end{array}$ & $\begin{array}{c}101 \\
(3.47)\end{array}$ & $\begin{array}{l}0.012 \\
(0.009)\end{array}$ \\
\hline Process documentation & 3 & Operations & $\begin{array}{c}89.0 \\
(3.51)\end{array}$ & $\begin{array}{l}106.9 \\
(3.49)\end{array}$ & $\begin{array}{c}99 \\
(3.64)\end{array}$ & $\begin{array}{l}0.030 * * * \\
(0.009)\end{array}$ \\
\hline Performance tracking & 4 & Monitoring & $\begin{array}{c}98.3 \\
(3.19)\end{array}$ & $\begin{array}{l}109.5 \\
(3.17)\end{array}$ & $\begin{array}{c}111 \\
(3.32)\end{array}$ & $\begin{array}{l}0.018 * * \\
(0.009)\end{array}$ \\
\hline Performance review & 5 & Monitoring & $\begin{array}{c}94.7 \\
(2.99)\end{array}$ & $\begin{array}{l}110.2 \\
(2.97)\end{array}$ & $\begin{array}{c}104 \\
(3.10)\end{array}$ & $\begin{array}{l}0.016^{*} \\
(0.009)\end{array}$ \\
\hline Performance dialogue & 6 & Monitoring & $\begin{array}{c}93.0 \\
(3.19)\end{array}$ & $\begin{array}{l}103.3 \\
(3.11)\end{array}$ & $\begin{array}{c}99 \\
(3.27)\end{array}$ & $\begin{array}{l}0.019 * * \\
(0.009)\end{array}$ \\
\hline Consequence management & 7 & Monitoring & $\begin{array}{l}96.5 \\
(3.02)\end{array}$ & $\begin{array}{l}108.7 \\
(3.01)\end{array}$ & $\begin{array}{c}94 \\
(3.13)\end{array}$ & $\begin{array}{l}0.019 * * \\
(0.009)\end{array}$ \\
\hline Target breadth & 8 & Targets & $\begin{array}{c}91.1 \\
(3.53)\end{array}$ & $\begin{array}{c}93.3 \\
(3.51)\end{array}$ & $\begin{array}{c}94 \\
(3.66)\end{array}$ & $\begin{array}{l}0.027 * * * \\
(0.009)\end{array}$ \\
\hline Target interconnection & 9 & Targets & $\begin{array}{l}93.7 \\
(3.56)\end{array}$ & $\begin{array}{c}97.3 \\
(3.54)\end{array}$ & $\begin{array}{c}78 \\
(3.68)\end{array}$ & $\begin{array}{l}0.023^{* * *} \\
(0.009)\end{array}$ \\
\hline Target time horizon & 10 & Targets & $\begin{array}{l}91.9 \\
(3.69)\end{array}$ & $\begin{array}{c}98.6 \\
(3.66)\end{array}$ & $\begin{array}{c}92 \\
(3.83)\end{array}$ & $\begin{array}{l}0.021^{* *} \\
(0.009)\end{array}$ \\
\hline Targets are stretching & 11 & Targets & $\begin{array}{l}87.8 \\
(3.34)\end{array}$ & $\begin{array}{l}104.9 \\
(3.32)\end{array}$ & $\begin{array}{c}101 \\
(3.45)\end{array}$ & $\begin{array}{r}0.015^{*} \\
(0.009)\end{array}$ \\
\hline $\begin{array}{l}\text { Performance clarity and } \\
\text { comparability }\end{array}$ & 12 & Monitoring & $\begin{array}{l}93.7 \\
(3.53)\end{array}$ & $\begin{array}{c}80.7 \\
(3.49)\end{array}$ & $\begin{array}{c}83 \\
(3.65)\end{array}$ & $\begin{array}{l}0.008 \\
(0.009)\end{array}$ \\
\hline Managing human capital & 13 & Targets & $\begin{array}{c}89.4 \\
(3.94)\end{array}$ & $\begin{array}{c}99.0 \\
(3.92)\end{array}$ & $\begin{array}{c}89 \\
(4.08)\end{array}$ & $\begin{array}{l}0.023^{* *} \\
(0.009)\end{array}$ \\
\hline $\begin{array}{l}\text { Rewarding high } \\
\text { performance }\end{array}$ & 14 & Incentives & $\begin{array}{l}81.6 \\
(3.42)\end{array}$ & $\begin{array}{c}85.2 \\
(3.42)\end{array}$ & $\begin{array}{c}85 \\
(3.55)\end{array}$ & $\begin{array}{l}0.022^{* *} \\
(0.010)\end{array}$ \\
\hline Removing poor performers & 15 & Incentives & $\begin{array}{c}89.4 \\
(3.04)\end{array}$ & $\begin{array}{c}92.5 \\
(3.02)\end{array}$ & $\begin{array}{c}83 \\
(3.15)\end{array}$ & $\begin{array}{c}0.011 \\
(0.009)\end{array}$ \\
\hline Promoting high performers & 16 & Incentives & $\begin{array}{l}90.2 \\
(2.86)\end{array}$ & $\begin{array}{l}104.9 \\
(2.85)\end{array}$ & $\begin{array}{c}92 \\
(2.97)\end{array}$ & $\begin{array}{c}0.017^{*} \\
(0.010)\end{array}$ \\
\hline Attracting human capital & 17 & Incentives & $\begin{array}{c}90.4 \\
(2.89)\end{array}$ & $\begin{array}{c}95.1 \\
(2.88)\end{array}$ & $\begin{array}{c}85 \\
(2.99)\end{array}$ & $\begin{array}{l}0.029 * * * \\
(0.009)\end{array}$ \\
\hline Retaining human capital & 18 & Incentives & $\begin{array}{l}93.6 \\
(2.74)\end{array}$ & $\begin{array}{c}97.7 \\
(2.73)\end{array}$ & $\begin{array}{c}97 \\
(2.84)\end{array}$ & $\begin{array}{l}0.007 \\
(0.009)\end{array}$ \\
\hline Unweighted Average & & & 91.5 & 98.7 & 93.8 & $\begin{array}{c}0.019 \\
(0.009)\end{array}$ \\
\hline
\end{tabular}

NOTES: In columns (1) to (3) standard deviation of each question's average response are reported below in brackets. Calculated from full sample of 732 firms. Management z-scores used in these calculations. In column (4) results from 18 OLS estimations following exactly the same specification as column (1) Table (2) except estimated with each individual question z-score one-by-one rather than the average management z-score. So every cell in column (4) is from a different regression with 5350 observations from 709 firms where: standard errors in parentheses allow for arbitrary heteroskedacity and correlation (clustered by firm), and regression includes "full controls" comprising of "firm" controls and "noise controls" as detailed in Table 2. *** denotes $1 \%$ significance, ** denoted $5 \%$ significance and * denotes $1 \%$ significance. 


\section{APPENDIX A2: HUMAN RESOURCES INTERVIEW GUIDE}

\section{Run in parallel as the management survey but targeted at the HR department}

\section{Workforce Characteristics}

Data Field

Total number of employees (cross check again accounts)

$\%$ with university degree

$\%$ with MBA

Average age of employees

$\%$ of employees

Average training days per year

Average hours worked per week (including overtime, excludin

Average holidays per year

Average days sick-leave

$\%$ part-time

$\%$ female

$\%$ employees abroad

$\%$ union membership

Are unions recognized for wages bargaining [yes / no]

\section{Work-life Balance Outcome Measure:}

\section{Question}

Relative to other companies in your industry

how much does your company emphasize

work-life balance?

\section{Work-Life Balance Practices:}

Question

If an employee needed to take a day off at short due child-care problems or their child was sick how do they generally do this?

What entitlements are there to the following

Working at home in normal working hours?

Switching from full-time to part-time work?

Job sharing schemes?

Financial subsidy to help pay for childcare?

\section{Organizational Characteristics}

Question

Who decides the pace of work?

Who decides how tasks should be allocated?

Do you use self-managing teams?

\section{Market \& firm questions:}

\# of competitors

\# hostile take-over bids in last three years

Interviewer's assessment of the scoring reliability

1 to 5 scoring system calibrated according to:

1 = Interviewee did not have enough expertise for interview to be valuable; I have significant doubts about most of the management dimensions probed

$3=$ Interviewee had reasonable expertise; on some dimensions I am unsure of scoring

5 = Interviewee had good expertise, I am confident that the score reflects management practices in this firm
Breakdown

(all employees)

(all employees)

(all employees)

(all employees)

(managerial/non-managerial)

(all employees)

(all employees)

(managerial/non-managerial)

(managerial/non-managerial)

(all employees)

(all employees)

(all employees)

Response choice (all employees)

[much less / slightly less / the same / slightly

more / much more]

Response choice (managerial/non-managerial) [Not allowed / Never Been Asked / Take as leave without pay / Take time off but make it up later / Take as annual leave / Take as sick leave]

Breakdown

(managerial/non-managerial)

(managerial/non-managerial)

(managerial/non-managerial)

(managerial/non-managerial)

Response choice (all employees)

[exclusively workers / mostly workers / equally / mostly managers / exclusively managers] [exclusively workers / mostly workers/ equally / mostly managers / exclusively managers]

[v. heavily / heavily / moderately / slightly / none] Response choice

[none / less than 5 / 5 or more]

[none / one / more than one ] (managerial/non-managerial) 


\section{APPENDIX B: DATA}

\section{Sampling Frame Construction}

Our sampling frame was based on the Amadeus dataset for Europe (UK, France and Germany) and the Compustat dataset for the USA. These all have information on company accounting data. We chose firms whose principal industry was in manufacturing and who employed (on average between 2000 and 2003) no less than 50 employees and no more than 10,000 employees. We also removed any clients of the consultancy firm we worked with from the sampling frame (33 out of 1,353 firms).

Our sampling frame is reasonably representative of medium sized manufacturing firms. The European firms in Amadeus include both private and public firms whereas Compustat only includes publicly listed firms. There is no US database with privately listed firms with information on sales, labor and capital. Fortunately, there are a much larger proportion of firms listed on the stock exchange in the US than in Europe so we were able to go substantially down the size distribution using Compustat. Nevertheless, the US firms in our sample are slightly larger than those of the other countries, so we were always careful to control for size and public listing in the analyses. Furthermore, when estimating production functions we could allow all coefficients to be different on labor, capital, materials and consolidation status by country.

Another concern is that we conditioned on firms where we have information on sales, employment and capital. These items are not compulsory for firms below certain size thresholds so disclosure is voluntary to some extent for the smaller firms. Luckily, the firms in our sampling frame (over 50 workers) are past the threshold for voluntary disclosure (the only exception is for capital in Germany).

We achieved a response rate of 54\% from the firms that we contacted: a very high success rate given the voluntary nature of participation. Respondents were not significantly more productive than non-responders. French firms were slightly less likely to respond than firms in the other three countries and all respondents were significantly larger than nonrespondents. Apart from these two factors, respondents seemed randomly spread around our sampling frame

\section{Firm Level Data}

Our firm accounting data on sales, employment, capital, profits, shareholder equity, long-term debt, market values (for quoted firms) and wages (where available) came from Amadeus (France, Germany and the UK) and Compustat (US). For other data fields we did the following:

Materials: In France and Germany these are line items in the accounts. In the UK these were constructed by deducting the total wage bill from the cost of goods sold. In the US these were constructed following the method in Bresnahan et al. (2002). We start with costs of good sold (COGS) less depreciation (DP) less labor costs (XLR). For firms who do not report labor expenses expenditures we use average wages and benefits at the four-digit industry level (Bartelsman, Becker and Gray, 2000, until 1996 and then Census Average Production Worker Annual Payroll by 4-digit NAICS code) and multiply this by the firm's reported employment level. This constructed measure is highly correlated at the industry level with materials. 
Obviously there may be problems with this measure of materials (and therefore value added) which is why we check robustness to measures without materials.

\section{Industry Level Data}

This comes from the OECD STAN database of industrial production. This is provided at the country ISIC Rev. 3 level and is mapped into US SIC (1997) three (which is our common industry definition in all four countries). 


\begin{tabular}{|c|c|c|c|c|c|}
\hline & All & France & Germany & UK & US \\
\hline Number of firms, \# & 732 & 135 & 156 & 151 & 290 \\
\hline Work-life balance & 3.21 & 3.44 & 3.03 & 3.19 & 3.22 \\
\hline Management (mean z score) & -0.001 & -0.084 & 0.032 & -0.150 & 0.097 \\
\hline Employment (mean) & 1,984 & 1,213 & 1,816 & 1,735 & 2,569 \\
\hline Labor share of output, $\%$ & 26.4 & 23.5 & 28.2 & 27.2 & 28.0 \\
\hline Tobin's Q & 1.71 & 1.16 & 1.86 & 2.01 & 0.88 \\
\hline Nominal sales growth rate, \% & 6.0 & 5.4 & 3.8 & 6.8 & 7.2 \\
\hline Age of firm (years) & 53.4 & 38.6 & 86.8 & 44.7 & 48.4 \\
\hline Listed firm, \% & 57.2 & 16.1 & 41.0 & 28.5 & 100 \\
\hline Multinational subsidiary, \% & 5.1 & 8.9 & 7.1 & 9.3 & 0 \\
\hline Share workforce with degrees, \% & 21.2 & 15.5 & 14.3 & 14.0 & 31.0 \\
\hline Share workforce with an MBA, \% & 1.36 & 0.23 & 0.09 & 1.28 & 2.73 \\
\hline Sickness, days/year & 6.80 & 8.16 & 8.51 & 6.21 & 5.01 \\
\hline Hours, hours per week & 40.7 & 35.6 & 38.6 & 40.8 & 44.1 \\
\hline Holidays, days per year & 22.7 & 32.2 & 29.7 & 26.9 & 12.4 \\
\hline Union density, \% & 19.9 & 9.7 & 41.4 & 25.3 & 9.4 \\
\hline $\begin{array}{l}\text { Number of competitors index, } \\
\text { 1=“none", 2=“a few", 3=“many" }\end{array}$ & 2.47 & 2.32 & 2.35 & 2.53 & 2.56 \\
\hline $\begin{array}{l}\text { Lerner index, excluding the firm } \\
\text { itself }\end{array}$ & 0.055 & 0.040 & 0.071 & 0.040 & 0.060 \\
\hline Trade Openness (imports/output) & 0.31 & 0.33 & 0.32 & 0.42 & 0.24 \\
\hline $\begin{array}{l}\text { Childcare flexibility (see Appendix } \\
\text { A2, } 1 \text { is none and } 3 \text { is maximum) }\end{array}$ & 2.82 & 2.75 & 2.85 & 2.82 & 2.85 \\
\hline $\begin{array}{l}\text { Working from home (\% that allow } \\
\text { this) }\end{array}$ & 31.6 & 23.4 & 31.7 & 44.1 & 30.1 \\
\hline $\begin{array}{l}\text { Switching from full-time to part- } \\
\text { time (\% that allow this) }\end{array}$ & 48.0 & 76.5 & 61.5 & 43.7 & 27.8 \\
\hline Job-sharing (\% that allow this) & 10.0 & 21.0 & 7.7 & 15.5 & 3.6 \\
\hline $\begin{array}{l}\text { Childcare subsidy (\% that provide } \\
\text { this) }\end{array}$ & 16.6 & 58.5 & 5.3 & 3.4 & 8.4 \\
\hline
\end{tabular}

Notes: Data descriptive calculated on the full sample of 732 firms for which management information is available. 


\section{TABLE C1: CONTROLS FOR MEASUREMENT ERROR}

\begin{tabular}{|c|c|c|c|c|}
\hline \multicolumn{5}{|c|}{ Dependent variable is Management z-score } \\
\hline Explanatory Variable & Definition & Mean & Coefficient (s.e.) & Coefficient (s.e.) \\
\hline Male & Respondent is male & 0.982 & $\begin{array}{l}-0.277 \\
(0.128)\end{array}$ & $\begin{array}{l}-0.298 \\
(0.127)\end{array}$ \\
\hline Seniority & $\begin{array}{l}\text { The position of manager in the } \\
\text { organization ( } 1 \text { to } 5 \text { ) }\end{array}$ & 3.08 & $\begin{array}{c}0.074 \\
(0.026)\end{array}$ & $\begin{array}{c}0.073 \\
(0.026)\end{array}$ \\
\hline Tenure in this post & Years with current job title & 4.88 & $\begin{array}{l}-0.011 \\
(0.007)\end{array}$ & $\begin{array}{c}-0.009 \\
(0.006)\end{array}$ \\
\hline Tenure in the company & Years with the company & 11.7 & $\begin{array}{c}0.002 \\
(0.004)\end{array}$ & \\
\hline Countries & $\begin{array}{l}\text { Total number of countries } \\
\text { worked in over last ten years }\end{array}$ & 1.19 & $\begin{array}{c}0.085 \\
(0.048)\end{array}$ & $\begin{array}{c}0.092 \\
(0.043)\end{array}$ \\
\hline Organizations & $\begin{array}{l}\text { Total number of organizations } \\
\text { worked in over last ten years }\end{array}$ & 1.66 & $\begin{array}{l}-0.009 \\
(0.032)\end{array}$ & \\
\hline Manager is foreign & $\begin{array}{l}\text { Manager was born outside the } \\
\text { country s/he works }\end{array}$ & 0.032 & $\begin{array}{l}-0.048 \\
(0.142)\end{array}$ & \\
\hline Ever worked in USA & $\begin{array}{l}\text { The manager has worked in the } \\
\text { USA at some point }\end{array}$ & 0.425 & $\begin{array}{c}0.103 \\
(0.152)\end{array}$ & \\
\hline Location of manager & $\begin{array}{l}\text { Manager based on site (rather } \\
\text { than in corporate HQ) }\end{array}$ & 0.778 & $\begin{array}{c}0.011 \\
(0.063)\end{array}$ & \\
\hline Tuesday & $\begin{array}{l}\text { Day of the week that interview } \\
\text { was conducted, (Monday base) }\end{array}$ & 0.181 & $\begin{array}{c}0.011 \\
(0.062)\end{array}$ & $\begin{array}{c}0.016 \\
(0.086)\end{array}$ \\
\hline Wednesday & $\begin{array}{l}\text { Day of the week that interview } \\
\text { was conducted, (Monday base) }\end{array}$ & 0.280 & $\begin{array}{c}0.017 \\
(0.084)\end{array}$ & $\begin{array}{c}0.014 \\
(0.080)\end{array}$ \\
\hline Thursday & $\begin{array}{l}\text { Day of the week that interview } \\
\text { was conducted, (Monday base) }\end{array}$ & 0.195 & $\begin{array}{c}0.183 \\
(0.088)\end{array}$ & $\begin{array}{c}0.176 \\
(0.088)\end{array}$ \\
\hline Friday & $\begin{array}{l}\text { Day of the week that interview } \\
\text { was conducted, (Monday base) }\end{array}$ & 0.165 & $\begin{array}{c}0.059 \\
(0.090)\end{array}$ & $\begin{array}{c}0.054 \\
(0.090)\end{array}$ \\
\hline Local time for manager & $\begin{array}{l}\text { The time of the day ( } 24 \text { hour } \\
\text { clock) interview conducted }\end{array}$ & 12.45 & $\begin{array}{l}-0.023 \\
(0.010)\end{array}$ & $\begin{array}{l}-0.022 \\
(0.010)\end{array}$ \\
\hline $\begin{array}{l}\text { Days from start of } \\
\text { project }\end{array}$ & $\begin{array}{l}\text { Count of days since start of the } \\
\text { project }\end{array}$ & 39 & $\begin{array}{c}0.001 \\
(0.001)\end{array}$ & \\
\hline Duration of interview & $\begin{array}{l}\text { The length of the interview with } \\
\text { manager (in minutes) }\end{array}$ & 46.0 & $\begin{array}{c}0.008 \\
(0.003)\end{array}$ & $\begin{array}{c}0.007 \\
(0.003)\end{array}$ \\
\hline Number of contacts & $\begin{array}{l}\text { Number of telephone calls to } \\
\text { arrange the interview }\end{array}$ & 5.73 & $\begin{array}{c}0.007 \\
(0.006)\end{array}$ & \\
\hline Reliability score & $\begin{array}{l}\text { Interviewer's subjective ranking } \\
\text { of interview reliability (1 to 5) }\end{array}$ & 4.15 & $\begin{array}{c}0.326 \\
(0.034) \\
\end{array}$ & $\begin{array}{c}0.327 \\
(0.033) \\
\end{array}$ \\
\hline $\begin{array}{l}17 \text { Interviewer } \\
\text { Dummies }\end{array}$ & & & $\begin{array}{c}F(15,699)=3.05 \\
p-\text { value }=0.000\end{array}$ & $\begin{array}{c}F(15,699)=3.46 \\
p-\text { value }=0.000\end{array}$ \\
\hline
\end{tabular}

